Pacific Northwest

National Laboratory

Operated by Battelle for the

U.S. Department of Energy

\section{RCRA Groundwater Quality Assessment Report for Single- Shell Tank Waste Management Area TX-TY (January 1998 through December 2001)}

D. G. Horton

October 2002

Prepared for the U.S. Department of Energy under Contract DE-AC06-76RL01830 


\section{DISCLAIMER}

This report was prepared as an account of work sponsored by an agency of the United States Government. Reference herein to any specific commercial product, process, or service by trade name, trademark, manufacturer, or otherwise does not necessarily constitute or imply its endorsement, recommendation, or favoring by the United States Government or any agency thereof, or Battelle Memorial Institute.

\section{PACIFIC NORTHWEST NATIONAL LABORATORY \\ operated by \\ BATTELLE \\ for the \\ UNITED STATES DEPARTMENT OF ENERGY \\ under Contract DE-AC06-76RL01830}

Printed in the United States of America

Available to DOE and DOE contractors from the

Office of Scientific and Technical Information, P.O. Box 62, Oak Ridge, TN 37831;

prices available from (615) 576-8401.

Available to the public from the National Technical Information Service, U.S. Department of Commerce, 5285 Port Royal Rd., Springfield, VA 22161

4 This document was printed on recycled paper. 


\section{RCRA Groundwater Quality Assessment Report for Single-Shell Tank Waste Management Area TX-TY \\ (January 1998 through December 2001)}

D. G. Horton

October 2002

Prepared for

the U.S. Department of Energy

under Contract DE-AC06-76RL01830

Pacific Northwest National Laboratory

Richland, Washington 99352 


\section{Summary}

Waste Management Area (WMA) TX-TY at the Hanford Site contains the TX and TY single-shell tank farms and their auxiliary equipment. These tank farms, located in the northern portion of the 200 West Area, include 24 single-shell carbon steel tanks constructed in the 1940s and early 1950s. During operations, tanks received mixed waste from plants that processed spent reactor fuel to recover plutonium as part of Hanford's defense mission. The tank farms ceased active operations in 1980 but are currently storing waste and are currently regulated as Resource Conservation and Recovery Act (RCRA) Interim Status Facilities.

Waste Management Area TX-TY was placed in RCRA Groundwater Quality Assessment in 1993 and has remained in that status because of indications that dangerous-waste contaminants from within the area may be entering groundwater.

The water table is declining and groundwater flow directions are changing in the vicinity of WMA TX-TY. These changes are a result of the cessation of effluent discharge to ground in 1995 and the initiation of a major pump-and-treat operation in 1998. To meet the changing groundwater monitoring needs, twelve new RCRA monitoring wells have been constructed since 1997 and two others are in the planning stage.

Monitoring at WMA TX-TY indicates that the dangerous-waste constituent chromium occurs above the drinking water maximum contaminant level at one well east of the WMA. Although the nearest potential source for the chromium is the WMA and the chromium is attributed to the WMA, the high concentrations of chromium appear to be deeper in the aquifer than the maximum concentrations of nonregulated technetium-99, which is most likely from WMA TX-TY. Chromium contamination is located on the downgradient (east) side of the WMA and is currently migrating to the southeast.

The dangerous-waste constituent carbon tetrachloride is also present at WMA TX-TY. The carbon tetrachloride is from a well document, upgradient source associated with the Plutonium Finishing Plant. Data gathered during drilling indicates that the carbon tetrachloride is distributed relatively deep in the upper part of the aquifer at WMA TX-TY. 


\section{Contents}

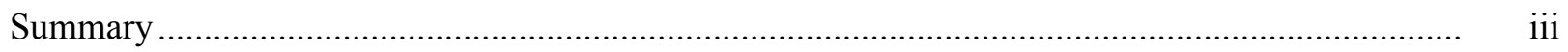

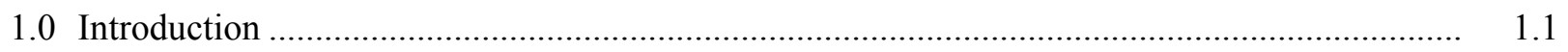

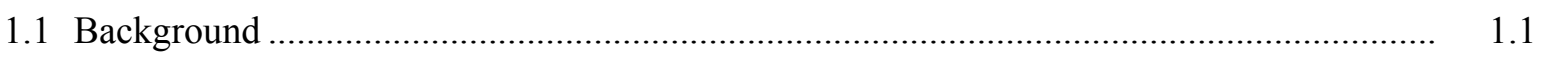

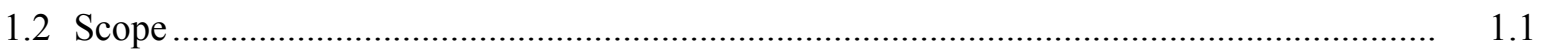

1.3 Basis for Groundwater Assessment at WMA TX-TY ................................................ 1.4

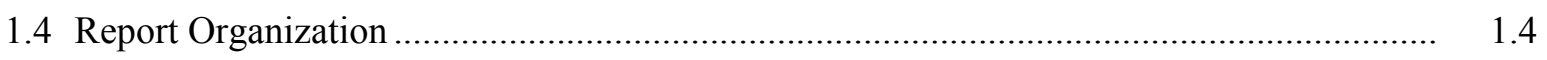

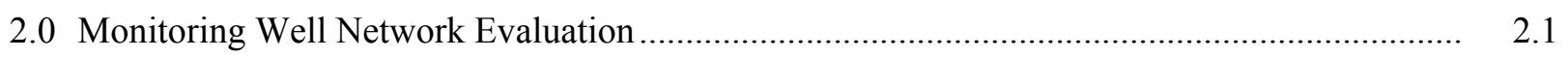

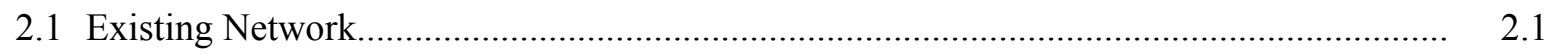

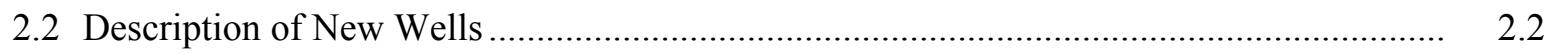

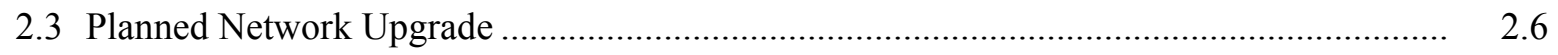

3.0 Rate and Direction of Groundwater Flow ..............................................................

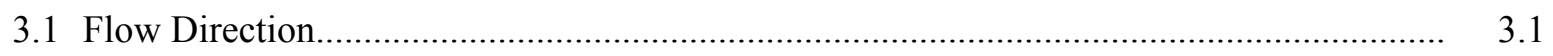

3.2 Borehole Tracer Dilution and Tracer Pumpback Testing .............................................. 3.3

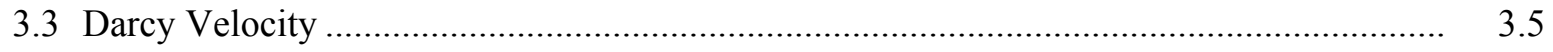

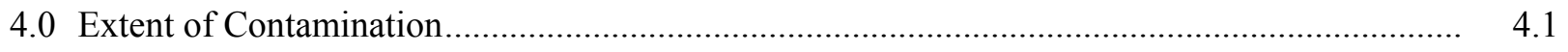

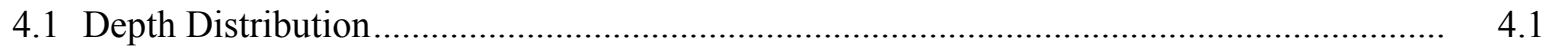

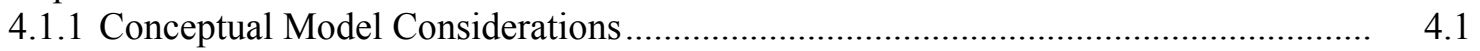

4.1.2 Vertical Distribution Data......................................................................... 4.2

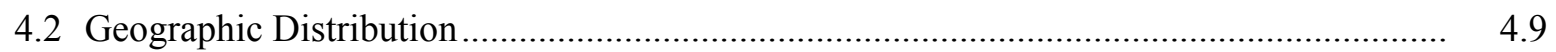

4.2.1 Chromium Upgradient of WMA TX-TY ....................................................... 4.10

4.2.2 Chromium Downgradient of Waste Management Area TX-TY ............................. 4.10

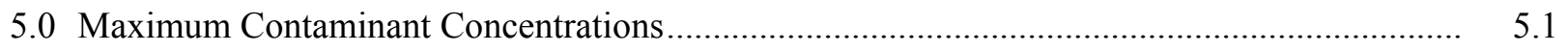

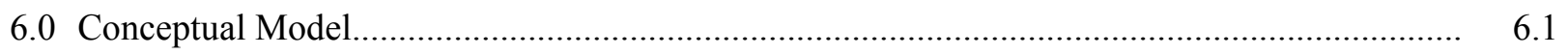

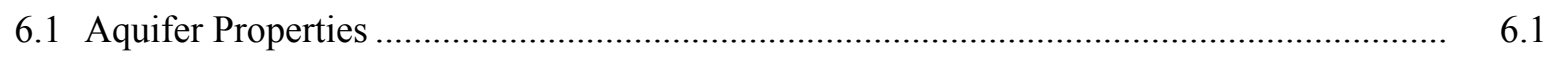

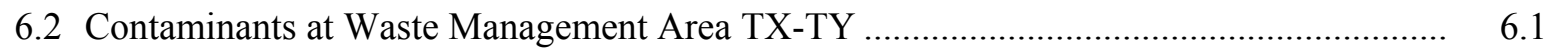

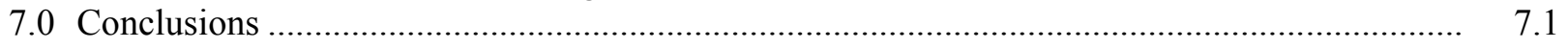


7.1 Rate and Extent of Contaminant Migration

7.2 Concentration of Contaminants.

7.3 Well Network

8.0 References

\section{Figures}

1.1 Location of Waste Management Area TX-TY on the Hanford Site.

1.2 Waste Management Area TX-TY, Surrounding Facilities, and Monitoring Well Locations.... 1.3

3.1 Water-Table Elevation Map for Waste Management Area TX-TY _.................................... 3.2

4.1 Chromium Concentrations in Filtered Samples from Wells 299-W14-12 and 299-W14-13 at Waste Management Area TX-TY

4.2 Technetium-99 Concentrations in Wells 299-W14-12 and 299-W14-13 in Waste Management Area TX-TY.

4.3 Chromium Concentrations in Filtered Samples from Wells 299-W10-18 and 299-W10-26 ....

4.4 Chromium Concentrations in Filtered Samples from Wells 299-W15-12 and 299-W15-765 at Waste Management Area TX-TY

4.5 Chromium Concentrations in Upgradient Wells at Waste Management Area TX-TY

4.6 Chromium Plume Map at Waste Management Area TX-TY for the Fourth Quarter of Calendar Year 2001 


\section{Tables}

2.1 Construction and Lithologic Characteristics of the Screen Intervals of New Wells at Waste Management Area TX-TY.

2.2 Development Pumping Data for Wells Drilled at Waste Management Area TX-TY since 1998 .

3.1 In-Well, Downward Vertical, Flow-Velocity Summary for Wells 299-W10-26 and 299-W14-13 at Waste Management Area TX-TY

3.2 Results from Tracer-Dilution and Tracer-Pumpback Tests in Wells at Waste Management Area TX-TY.

3.3 Hydraulic Properties from Slug and Constant Rate Pumping Tests and Calculated Darcy Velocities at New Wells at Waste Management Area TX-TY .....

3.4 Tracer-Dilution Test Results for Well 299-W15-41 at Waste Management Area TX-TY ....... 3.5

4.1 Discrete Depth Sampling Results from Well 299-W14-14 _............................................ 4.7

4.2 Analytical Results for Groundwater Samples Taken During Drilling of New Wells at Waste Management Area TX-TY.

4.3 Specific Conductance and pH for Samples from Wells 299-W14-18 and 299-W15-765 at Waste Management Area TX-TY. 


\subsection{Introduction}

This report presents the findings of continued groundwater quality assessment at Waste Management Area (WMA) TX-TY in the 200 West Area of the Hanford Site (Figure 1.1). This report covers the period between January 1998 and December 2001.

\subsection{Background}

Waste Management Area TX-TY was placed in groundwater quality assessment monitoring status in 1993 (Caggiano and Chou 1993). An initial assessment report, based on the results of a first determination, was issued in February 1998 and concluded the waste management area was contributing to groundwater contamination (Hodges 1998). Thus, a continued assessment of the concentrations of contaminants and the rate and extent of hazardous waste constituents is required [40 CFR 265.93(7)]. Accordingly, an assessment plan (Hodges and Chou 2001) was prepared to obtain the data needed to determine the rate and extent of contaminant migration and contaminant concentrations in the groundwater. Summary information on assessment results is included in quarterly reports to the Washington State Department of Ecology (Ecology) and annually, as required, in the groundwater monitoring annual reports, e.g., Hartman et al. (2002). A map showing WMA TX-TY, associated groundwater monitoring wells, and surrounding facilities is presented in Figure 1.2.

In addition to the groundwater monitoring done by the Hanford Groundwater Monitoring Project to track the extent and rate of movement of groundwater contamination, the Office of River Protection has begun to implement corrective actions at single-shell tank waste management areas. Initial corrective actions have included construction of berms around waste management areas and turning off known, old water lines that cross the waste management areas. Studies are underway to determine the best future corrective actions that may include institutional controls, engineered barriers, waste removal technologies, and in-situ and ex-situ treatment technologies (DOE/RL 2000). These corrective actions will help prevent future groundwater contamination from single-shell tank waste management areas.

\subsection{Scope}

Only new water quality data and hydrologic testing results obtained subsequent to the first assessment report are included in this report. Hydrogeology of the site, stratigraphy, waste site descriptions, and contaminant hydrology were described in the first assessment report (Hodges 1998) and in the updated assessment plan (Hodges and Chou 2001). Therefore, the scope of this report is limited to evaluation and interpretation of new data acquired from

- twelve new wells installed since January 1998

- groundwater sampling data collected during well drilling

- additional routine, quarterly sampling data collected from the existing network from January 1998 through December 2001. 


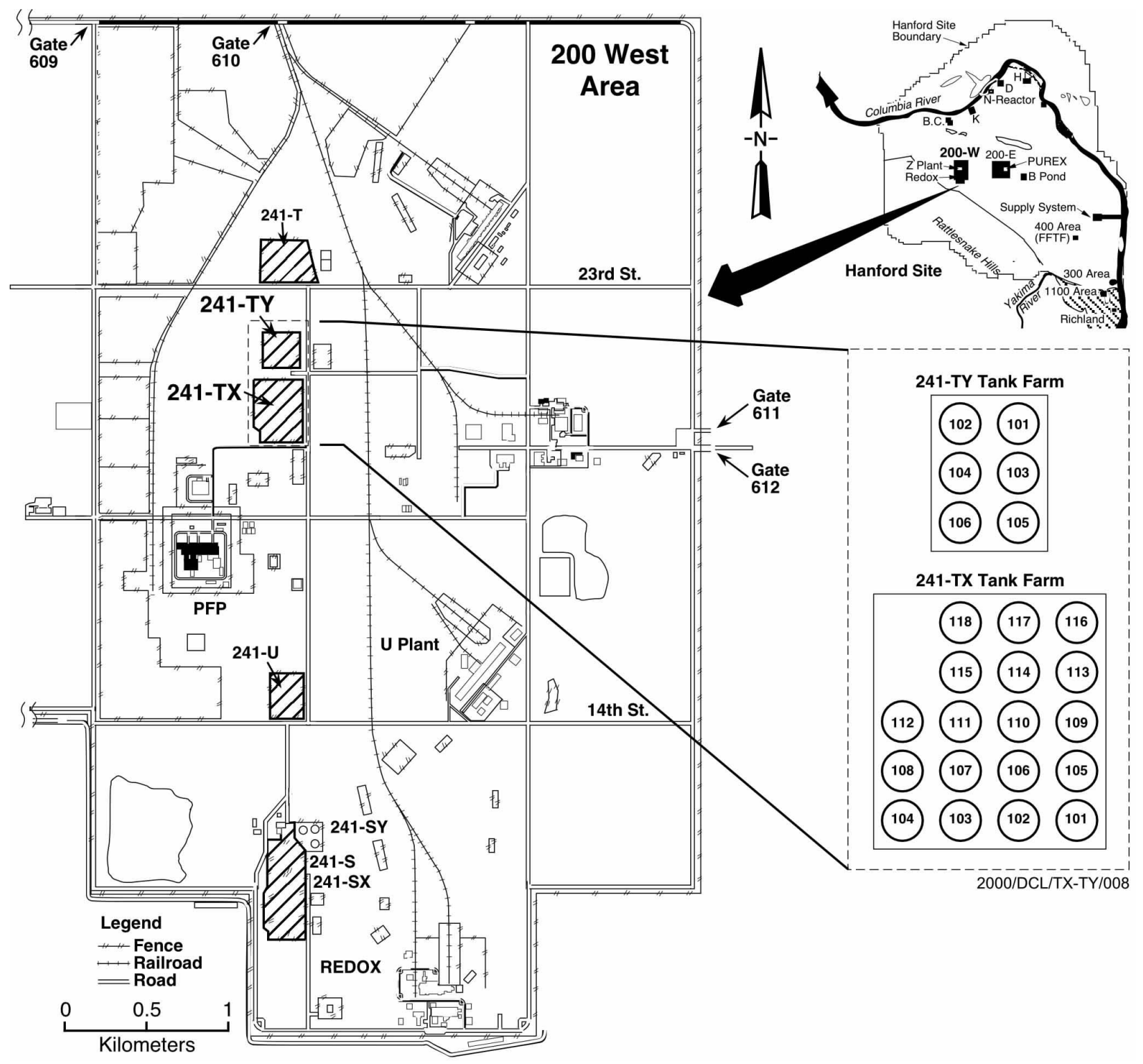

Figure 1.1. Location of Waste Management Area TX-TY on the Hanford Site 


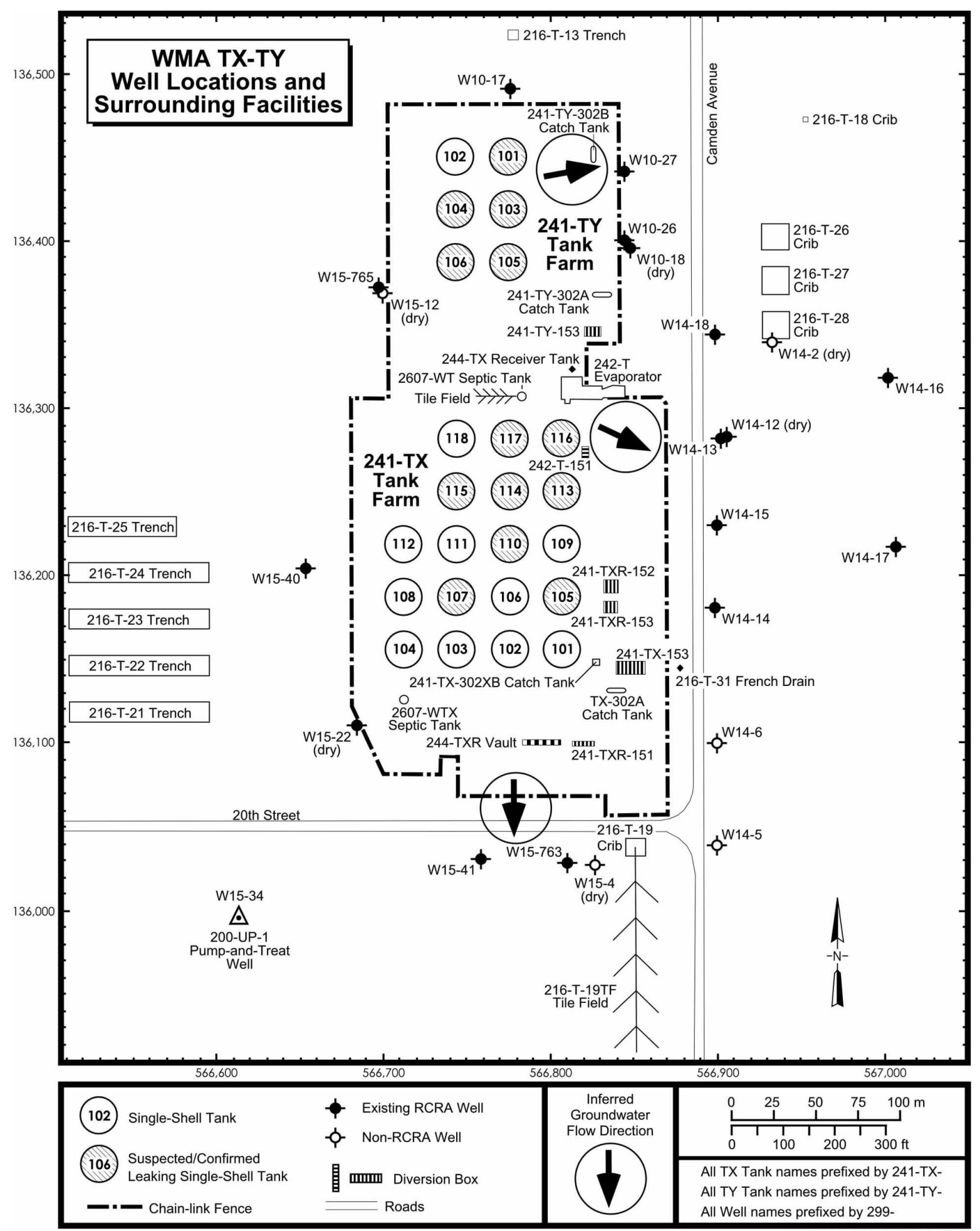

2002/DCL/TX-TY/019 (07/10)

Figure 1.2. Waste Management Area TX-TY, Surrounding Facilities, and Monitoring Well Locations 
Supporting information (e.g., drilling information and hydrologic testing raw data) for this report are available in the project files of the Hanford Groundwater Monitoring Project at Pacific Northwest National Laboratory (PNNL) and in the borehole data packages for the new wells that were drilled during the report period (Horton and Hodges 1999, 2000, 2001; Horton 2002a).

\subsection{Basis for Groundwater Assessment at WMA TX-TY}

Hodges and Chou (2001) described the objectives and general approach for assessment of groundwater quality at WMA TX-TY. Those objectives, as required by 40 CFR 265.93 (d) and WAC 173-303-400, are to determine

(i) the rate and extent of migration of the hazardous waste or hazardous waste constituents in the groundwater

(ii) the concentration of hazardous waste or hazardous waste constituents in the groundwater.

The assessment work done at WMA TX-TY during the reporting period to meet these objectives was described by Hodges and Chou (2001). The work included (1) installation of new wells to complete the monitoring well network in response to changing flow directions and declining water levels, (2) hydraulic testing of the new wells for determination of aquifer properties and groundwater flow rate and, (3) sampling the new wells to determine the vertical and lateral extent of contamination.

\subsection{Report Organization}

Organization of this report is based on the objectives for the continuing assessment, which are to determine the rate and extent of migration and the concentration of contaminants in groundwater. Accordingly, Chapter 2 describes the groundwater monitoring network, particularly salient information gathered from installation of new wells that may reflect conditions in the aquifer. Chapter 3 discusses the rate of groundwater movement and direction of flow based on hydrologic data acquired during the reporting period. Chapter 4 discusses the spatial and vertical extents of contamination, contaminant concentrations, and contaminant types based on new observations made during drilling of new monitoring wells for this assessment. Chapter 4 also provides some information obtained from routine quarterly sampling between January 1998 and December 2001. Chapter 5 provides information on the highest contaminant concentrations found at the WMA. Chapter 6 updates the conceptual model for WMA TX-TY with interpretations of data collected during the reporting period. Chapter 7 presents conclusions regarding the rate and extent of contaminant migration, possible source areas, and the likelihood of detecting groundwater contamination that could arise from this WMA in the future. 


\subsection{Monitoring Well Network Evaluation}

The groundwater monitoring network at WMA TX-TY has required continued modification, both because of a declining water table and because of changing groundwater flow directions. The locations of the RCRA monitoring wells, and non-RCRA wells used to supplement the groundwater quality assessment at the WMA TX-TY are shown in Figure 1.2.

\subsection{Existing Network}

Three of the original WAC 173-160 compliant wells at WMA TX-TY (299-W10-18, 299-W14-12, and 299-W15-22) are dry as a result of the declining water table. The last of the original WAC-compliant wells, 299-W10-17, is near the end of its useful life with less than 1 meter of water remaining in the well.

The current groundwater monitoring network at WMA TX-TY consists of 15 wells. Two of these wells, wells 299-W14-5 and 299-W14-6, are older wells constructed before WAC 173-160 was implemented and are used as downgradient wells on the southern part of the east side of the 241-TX tank farm. These older wells have 9 to 11 meters of perforated casing. Well 299-W10-17, constructed in 1990, is the only original WAC-compliant well still in use at WMA TX-TY. That well was originally located downgradient on the north side of 241-TY tank farm. Because of changes in groundwater flow direction since 1990, well 299-W10-17 is now lateral to the WMA with respect to groundwater flow.

Twelve new WAC-compliant wells have been installed at WMA TX-TY since 1998. Wells 299-W15-765 and 299-W15-40 are the new upgradient wells located west of 241-TY and 241-TX tank farms respectively. Wells 299-W15-763 and 299-W15-41 are new RCRA wells located south of the 241-TX tank farm. Under natural groundwater flow conditions, these wells would probably be lateral to the WMA; however, the 200-ZP-1 pump-and-treat operations, located south of the WMA, have altered groundwater flow beneath the 241-TX tank farm to a southerly direction so that these wells are downgradient monitoring wells.

The remaining eight wells in the monitoring network are located downgradient along the eastern boundary of the WMA. Two of these, wells 299-W14-16 and 299-W14-17, are located 130 meters east of the tank farm fence. The other six wells are near-field monitoring wells located within $\sim 30$ meters of the tank farm fence.

The groundwater monitoring network at WMA TX-TY is based on the current understanding of subsurface conditions. The initial network was designed based on professional judgment. Since the beginning of declining water levels in the area, the locations of wells were evaluated using a model (MEMO, Wilson et al. 1992). This provided an initial basis for the spacing and locations of wells. These wells have been effective in detecting contamination and defining plume contours.

The current well spacing on the downgradient side (east side) of WMA TX-TY ranges from 41 to 113 meters with all but one distance at less than 77 meters. The largest separation is between wells 
299-W14-14 and 299-W14-6 east of 241-TX tank farm. The groundwater in this area is affected by the 200-ZP-1 pump-and-treat operation such that these two wells currently are located upgradient or lateral to the WMA with respect to groundwater flow direction. Thus, the spacing between these two wells is of minimal concern to monitoring contaminants originating from the WMA until the pump-and-treat operations are stopped. The well spacing at WMA TX-TY is considered adequate if contaminant plumes can be mapped sufficiently for decision making purposes.

\subsection{Description of New Wells}

Details on the drilling and construction of new wells and on the geologic conditions encountered during drilling can be found in the borehole completion reports (Horton and Hodges 1999, 2000, 2001; Horton 2002a).

Twelve new wells have been installed at WMA TX-TY since 1998. Three of these wells (299-W10-26, 299-W14-13, and 299-W14-18) were drilled as replacements for existing, downgradient wells. Two of the new wells (299-W15-40 and 299-W15-765) were drilled as replacements for the original upgradient wells that have gone dry. Three of the new wells (299-W10-27, 299-W14-14, and 299-W14-15) were installed as new downgradient wells in response to changing groundwater flow directions and assessment monitoring objectives. Two new wells (299-W14-16 and 299-W14-17) were installed as downgradient wells to address assessment monitoring objectives (Hodges and Chou 2001). The remaining two new wells (299-W15-41 and 299-W15-763) were installed south of the 241-TX tank farm as downgradient wells in response to changes in flow directions due to the 200-ZP-1 pump-and-treat operations. Table 2.1 lists the new wells and information about each well pertinent to hydrogeologic characteristics of the screened intervals.

Some indications of aquifer properties are found from information in the geologist's logs made during drilling. Of particular interest are textural descriptions that may indicate variations in permeability. In general, better sorted sediments and sediments with less fine-grained material are expected to be more permeable than poorly-sorted or fine-grained sediments. For example, the description of the sediments through the screened interval of well 299-W15-765 notes changes from silty sandy gravel to relatively clean gravel in specific zones in the screened interval. Thus, the silt-poor zones are expected to be more permeable than the silt-rich zones in this well. Similar lithologic changes are suggested by wireline geophysical surveys for the screened interval in wells 299-W15-40 and 299-W15-763 and by the geologist's log and/or sieve analyses for wells 299-W10-27, 299-W14-14, 299-W14-15, 299-W14-16, and 299-W14-18. The geologists' logs, borehole geophysical logs, and sieve data are in the borehole completion reports for the wells (Horton and Hodges 1999, 2000, 2001; Horton 2002a).

Other potentially useful information can be gained by the geologists' comments. For example, the geologist noted that well 299-W14-16 took a long time for the water level to recover during drilling at a depth of 68.3 meters, suggesting that this part of the screened interval is relatively less permeable than

other parts of the screened interval. This interpretation is supported by the available data from sieve analyses which show that the sediment at a depth of 68 meters is silty sandy gravel whereas the sediment at 73 and 77 meters is sandy gravel. Also, the geologist noted differences in the water level during drilling of well 299-W15-41 depending on the depth of the temporary casing. These differences suggest 
Table 2.1. Construction and Lithologic Characteristics of the Screen Intervals of New Wells at Waste Management Area TX-TY ${ }^{(a)}$

\begin{tabular}{|c|c|c|c|c|c|c|c|}
\hline Well $^{(\mathrm{b})}$ & $\begin{array}{c}\text { Date } \\
\text { Drilled }\end{array}$ & $\begin{array}{l}\text { Drilling } \\
\text { Method }\end{array}$ & $\begin{array}{c}\text { Screen } \\
\text { Interval } \\
\text { Depth }(\mathrm{m})^{(\mathrm{c})} \\
\end{array}$ & $\begin{array}{l}\text { Pump Intake } \\
\text { Depth }(\mathrm{m})^{(\mathrm{c})}\end{array}$ & $\begin{array}{c}\text { Total Drill } \\
\text { Depth }(\mathrm{m})^{(\mathrm{c})}\end{array}$ & $\begin{array}{c}\text { Depth to } \\
\text { Water }^{(\mathrm{d})}(\mathrm{m})^{(\mathrm{c})}\end{array}$ & Comments \\
\hline W10-26 & $08 / 90$ & Air Rotary & $\begin{array}{c}66.15 \\
\text { to } \\
76.85\end{array}$ & 70.56 & 79.86 & 66.26 & $\begin{array}{l}\text { Silty sandy gravel throughout the } \\
\text { screened zone }{ }^{(e) .}\end{array}$ \\
\hline W10-27 & 01/01 & Cable tool & $\begin{array}{l}67.36 \\
\text { to } \\
77.11\end{array}$ & 76.50 & 81.90 & 67.25 & $\begin{array}{l}67.1 \text { to } 68.6 \mathrm{~m} \text { is slightly silty gravelly } \\
\text { sand with good penetration rate; } 68.6 \\
\text { to bottom of screened interval is silty } \\
\text { sandy gravel and very hard drilling.(e) } \\
\text { sieve analyses from sediment at } 69 \text { and } \\
73 \text { m yields silty sandy gravel, sieve } \\
\text { analysis from } 77.4 \mathrm{~m} \text { (below the } \\
\text { screen) is sandy gravel; geophysical } \\
\text { log indicates no significant change in } \\
\text { lithology in screened zone. }\end{array}$ \\
\hline W14-13 & $08 / 98$ & Air Rotary & $\begin{array}{l}66.02 \\
\text { to } \\
76.73\end{array}$ & 70.53 & 79.86 & 65.78 & $\begin{array}{l}\text { Moderately sorted silty sandy gravel } \\
\text { throughout screened interval. }{ }^{(\mathrm{e})}\end{array}$ \\
\hline W14-14 & $11 / 98$ & Air Rotary & $\begin{array}{l}66.14 \\
\text { to } \\
76.90\end{array}$ & 70.56 & 135.03 & 66.27 & $\begin{array}{l}\text { The upper } 0.3 \mathrm{~m} \text { of screened interval is } \\
\text { gravelly sand and the rest of the } \\
\text { screened interval is silty sandy } \\
\text { gravel. }^{(\mathrm{e})}\end{array}$ \\
\hline W14-15 & $08 / 00$ & Air Rotary & $\begin{array}{l}66.98 \\
\text { to } \\
77.61\end{array}$ & 67.27 & 79.25 & 67.27 & $\begin{array}{l}\text { Sandy gravel from above the screen to } \\
67.4 \mathrm{~m} \text { and silty sandy gravel from } \\
67.4 \mathrm{~m} \text { to below the bottom of the } \\
\text { screened interval; }^{(\mathrm{e})} \text { sieve analyses of } \\
\text { samples from } 68 \text { and } 72 \mathrm{~m} \text { show silty } \\
\text { sandy gravel, sieve analysis from a } \\
77 \mathrm{~m} \text { sample shows sandy gravel. }\end{array}$ \\
\hline W14-16 & $10 / 00$ & Air Rotary & $\begin{array}{l}67.95 \\
\text { to } \\
78.60\end{array}$ & 70.98 & 80.77 & 67.83 & $\begin{array}{l}\text { Sandy gravel throughout the screened } \\
\text { interval; }{ }^{(\mathrm{e})} \text { sieve analysis of sample } \\
\text { from } 68 \mathrm{~m} \text { is silty sandy gravel, sieve } \\
\text { analyses of samples from } 73 \text { and } 77 \mathrm{~m} \\
\text { are sandy gravel; geophysical log } \\
\text { indicates less silt between } \sim 70 \text { and } \\
76 \mathrm{~m} \text { depth. Water was added to the } \\
\text { borehole below the water table to aid } \\
\text { in removal of cuttings indicating a } \\
\text { fairly tight formation with slow } \\
\text { recovery. Geologist also noted that the } \\
\text { water level took a long time to } \\
\text { recover. }\end{array}$ \\
\hline W14-17 & $10 / 00$ & Air Rotary & $\begin{array}{l}67.6 \\
\text { to } \\
78.3\end{array}$ & 71 & 80.9 & 67.6 & $\begin{array}{l}\text { Sandy gravel throughout the screened } \\
\text { interval; }{ }^{(\mathrm{e})} \text { poor recovery of split spoon } \\
\text { samples at } 69.4 \text { and } 74.7 \mathrm{~m} \text { depths due } \\
\text { to dense gravels, good recovery at } \\
77.7 \mathrm{~m} \text { depth; }{ }^{(\mathrm{f})} \text { no distinct anomalies } \\
\text { in geophysical log. }\end{array}$ \\
\hline
\end{tabular}


Table 2.1. (contd)

\begin{tabular}{|c|c|c|c|c|c|c|c|}
\hline Well $^{(\mathrm{b})}$ & $\begin{array}{c}\text { Date } \\
\text { Drilled }\end{array}$ & $\begin{array}{l}\text { Drilling } \\
\text { Method }\end{array}$ & \begin{tabular}{|c|} 
Screen \\
Interval \\
Depth $(\mathrm{m})^{(\mathrm{c})}$ \\
\end{tabular} & $\begin{array}{l}\text { Pump Intake } \\
\text { Depth }(\mathrm{m})^{(\mathrm{c})}\end{array}$ & $\begin{array}{l}\text { Total Drill } \\
\text { Depth }(\mathrm{m})^{(\mathrm{c})}\end{array}$ & $\begin{array}{c}\text { Depth to } \\
\text { Water }^{(\mathrm{d})}(\mathrm{m})^{(\mathrm{c})}\end{array}$ & Comments \\
\hline W14-18 & $08 / 01$ & Cable Tool & $\begin{array}{c}66.5 \\
\text { to } \\
77.1\end{array}$ & 73.2 & 79.7 & 67.2 & $\begin{array}{l}\text { Borehole was drilled with hard tool } \\
\text { throughout screened interval; }{ }^{(\mathrm{f})} \\
\text { lithology is gravelly sandy silt between } \\
67 \text { and } 71.6 \mathrm{~m} \text { and between } 73.2 \text { and } \\
79.5 \mathrm{~m} \text { depths and gravelly silt between } \\
71.6 \text { and } 73.2 \mathrm{~m} \text { depth: }{ }^{(\mathrm{e})} \text { no distinct } \\
\text { changes noted on geophysical log. }\end{array}$ \\
\hline W15-40 & $08 / 98$ & \begin{tabular}{|c|} 
Cable Tool \\
from 0 to \\
$38.1 \mathrm{~m}$ and \\
Air Rotary \\
from 38.1 \\
to $80 \mathrm{~m}$
\end{tabular} & $\begin{array}{c}66.4 \\
\text { to } \\
77.1\end{array}$ & 70.5 & 80 & 66.5 & $\begin{array}{l}\text { Sandy gravel throughout the screened } \\
\text { interval; }{ }^{(\mathrm{e})} \text { geophysical log suggests } \\
\text { minor variations in gravel content } \\
\text { through screened interval. }\end{array}$ \\
\hline W15-41 & $11 / 99$ & Air Rotary & $\begin{array}{c}65.81 \\
\text { to } \\
70.4\end{array}$ & 66.7 & 72.8 & 65.0 & $\begin{array}{l}\text { Sandy gravel from } 65.5 \text { to } 69.2 \mathrm{~m} \text { depth } \\
\text { and silty sandy gravel from } 69.2 \text { to } \\
72.8 \mathrm{~m} \text { depth; } \text {; }^{(\mathrm{d})} \text { geophysical log shows } \\
\text { an increase in silt content with depth } \\
\text { throughout the screened interval; water } \\
\text { level was at } 65.1 \mathrm{~m} \text { with casing set at } \\
66.8 \mathrm{~m} \text { depth and at } 66.1 \mathrm{~m} \text { with casing } \\
\text { set at } 71.9 \mathrm{~m} \text { depth. }{ }^{(\mathrm{f})}\end{array}$ \\
\hline W15-763 & $11 / 00$ & $\begin{array}{l}\text { Cable Tool } \\
\text { from } 0 \text { to } \\
40.9 \mathrm{~m} \text { and } \\
\text { Air Rotary } \\
\text { from } 40.9 \\
\text { to } 78.5 \mathrm{~m}\end{array}$ & $\begin{array}{l}65.54 \\
\text { to } \\
75.2\end{array}$ & 69.4 & 78.5 & 66.1 & $\begin{array}{l}\text { Silty sandy gravel with iron oxide and } \\
\text { silica cement from } 64.3 \text { to } 66.8 \text { and } \\
\text { from } 73.2 \text { to } 78.3 \mathrm{~m} \text { depth, silty sandy } \\
\text { gravel from } 66.8 \text { to } 70.1 \text { and } 71.6 \text { to } \\
73.2 \mathrm{~m} \text { depth, and sandy gravel from } \\
70.1 \text { to } 71.6 \mathrm{~m} \text { depth; }{ }^{(\mathrm{e})} \text { slow driving } \\
\text { casing from } 71.6 \text { to } 73.4 \mathrm{~m} \text { depth, a lot } \\
\text { of water added to the borehole below } \\
\text { the water table to aid in bailing cuttings } \\
\text { and to control heaving sand; }{ }^{(f)} \text { sieve } \\
\text { analysis at } 66.1 \mathrm{~m} \text { is sandy gravel, sieve } \\
\text { analysis at } 70.7 \mathrm{~m} \text { is silty sandy gravel. }\end{array}$ \\
\hline W15-765 & $10 / 01$ & Air Rotary & $\begin{array}{l}67.1 \\
\text { to } \\
77.7\end{array}$ & 69.9 & 81.4 & 67 & $\begin{array}{l}67 \text { to } 70.1 \mathrm{~m} \text { depth is silty sandy gravel } \\
70.1 \text { to } 71.6 \mathrm{~m} \text { depth is gravel; } 71.6 \text { to } \\
73.2 \mathrm{~m} \text { depth is silty gravel; } 73.2 \text { to } \\
76.2 \mathrm{~m} \text { depth is silty sandy gravel; } \\
76.2 \text { to } 77.7 \mathrm{~m} \text { depth is gravel; } 77.7 \text { to } \\
80.6 \mathrm{~m} \text { depth is sandy gravel; } 80.6 \text { to } \\
80.7 \mathrm{~m} \text { depth is gravel. (e) }\end{array}$ \\
\hline \multicolumn{8}{|c|}{ (a) Information on well construction is from Horton and Hodges $(1999,2000,2001)$ and Horton $(2002 a)$. } \\
\hline
\end{tabular}


differences in recovery rates, which may reflect differences in lithology. Both the geophysical logs and the geologist's description of lithology for this well show differences in silt content corresponding to the zones with different groundwater recovery rates. Although these types of observations are subjective, they are valuable clues in deciphering aquifer properties.

Although not a controlled hydrologic test, the amount of drawdown during well development gives an indication of the relative permeability of the screened interval, or at least of some zone within the screened interval. These data are useful because well development is done routinely for all wells and, thus, is available for each well as opposed to other types of hydrologic test data. The pumping rate and amount of drawdown for all wells at WMA TX-TY drilled since 1998 are presented in Table 2.2. The

Table 2.2. Development Pumping Data for Wells Drilled at Waste Management Area TX-TY since 1998

\begin{tabular}{|c|c|c|c|c|c|}
\hline Well & Year Completed & $\begin{array}{l}\text { Pump Intake } \\
\text { Depth (m) }\end{array}$ & $\begin{array}{l}\text { Pumping Rate } \\
\text { (L/min) }\end{array}$ & $\begin{array}{c}\text { Drawdown } \\
(\mathrm{m})\end{array}$ & $\begin{array}{c}\text { Specific } \\
\text { Capacity } \\
(\mathrm{L} / \mathrm{min} / \mathrm{m})\end{array}$ \\
\hline \multirow{2}{*}{ 299-W10-26 } & \multirow{2}{*}{1990} & $\begin{array}{c}\text { Bottom of } \\
\text { Screened Interval }\end{array}$ & 34.1 & 1.6 & 21 \\
\hline & & $\begin{array}{c}\text { Middle of } \\
\text { Screened Interval }\end{array}$ & 37.8 & 1.3 & 29 \\
\hline \multirow{2}{*}{ 299-W10-27 } & \multirow{2}{*}{2001} & 76.7 & 26.5 & 8.2 & 3 \\
\hline & & 76.7 & 3.8 & 7.8 & 0.5 \\
\hline \multirow{2}{*}{ 299-W14-13 } & \multirow{2}{*}{1998} & $\begin{array}{c}\text { Bottom of } \\
\text { Screened Interval }\end{array}$ & 30.3 & 1.6 & 19 \\
\hline & & $\begin{array}{c}\text { Middle of } \\
\text { Screened Interval }\end{array}$ & 30.3 & 1.3 & 23 \\
\hline 299-W14-14 & 1998 & NA & NA & NA & - \\
\hline \multirow{2}{*}{ 299-W14-15 } & \multirow{2}{*}{2000} & 76.5 & 90.8 & 2.7 & 34 \\
\hline & & 71.0 & 94.6 & 2.6 & 36 \\
\hline \multirow{2}{*}{ 299-W14-16 } & \multirow{2}{*}{2000} & 78.3 & 90.8 & 4.5 & 20 \\
\hline & & 72.2 & 90.8 & NA & - \\
\hline \multirow{2}{*}{ 299-W14-17 } & \multirow{2}{*}{2000} & $\begin{array}{c}\text { Bottom of } \\
\text { Screened Interval }\end{array}$ & 87.1 & 2.7 & 32 \\
\hline & & $\begin{array}{c}\text { Middle of } \\
\text { Screened Interval }\end{array}$ & $64.3-75.7$ & 2.5 & $26-30$ \\
\hline \multirow{2}{*}{ 299-W14-18 } & \multirow{2}{*}{2001} & 75.6 & 37.9 & 6.2 & 6 \\
\hline & & 75.6 & 18.9 & 5.8 & 3 \\
\hline \multirow{2}{*}{ 299-W15-40 } & \multirow{2}{*}{1998} & 76.5 & 22.7 & 1.8 & 13 \\
\hline & & 71.6 & NA & 1.5 & - \\
\hline 299-W15-41 & 1999 & 69.5 & 98.4 & 1.0 & 98 \\
\hline \multirow{2}{*}{ 299-W15-763 } & \multirow{2}{*}{2000} & 73.1 & $18.9-22.7$ & 6.8 & 3 \\
\hline & & 69.4 & 18.2 & 1.0 & 18 \\
\hline \multirow{2}{*}{ 299-W15-765 } & \multirow{2}{*}{2001} & 77.0 & 113.6 & 1.4 & 81 \\
\hline & & 72.5 & 113.6 & 1.6 & 71 \\
\hline
\end{tabular}


specific capacity for each well is also shown on the table. The specific capacities were calculated from the pumping rate and drawdown measured during well development. The specific capacity is a measure of the yield of a well per unit of drawdown. All wells in Table 2.2 are screened in the Ringold Formation hydrogeologic unit 5 (Williams et al. 2002).

The data in Table 2.2 suggest that the screened interval in most wells is relatively permeable with little difference between the lower and middle portions of the screened intervals. Wells 299-W10-27 and 299-W14-18, however, appear to be screened in a much less permeable formation than the other wells. This is particularly so for well 299-W10-27, which had extreme drawdown with low pump rates and to which water had to be added during development to maintain a water level above the pump.

Also of note is the very transmissive nature of the screened interval in wells 299-W15-41 and 299-W15-765. Finally, the sediment around the screened interval in well 299-W15-763 appears to vary in permeability from relatively tight near the bottom of the screen to relatively transmissive near the middle of the screen.

The drawdown data from development pumping at well 299-W15-763 are also of note. Based on the drawdown information, there appears to be vertical differences in permeability of the sediments through the screened interval with the upper part being more permeable than the lower part. The geologist noted cemented zones interlayered with non-cemented zones in the upper part of the aquifer during drilling of this well.

Well-to-well variability in the permeability of the screened intervals noted at WMA TX-TY is similar to variability noted among the new wells installed at WMA T, slightly to the north of WMA TX-TY. Changes in the formation permeability seem to occur over short distances and are probably localized. This is illustrated by the variation in apparent permeability among wells 299-W10-26, 299-W10-27, and 299-W14-18 all of which are located in the northeast part of the WMA.

Changes in the permeability of the aquifer formation influence the results of groundwater sampling in that samples will contain a larger proportion of water from the more permeable zones. Also, heterogeneities in permeability can influence the distribution of contaminants in the aquifer. Contaminants entering the aquifer may not migrate vertically through a "tight" zone in the formation.

\subsection{Planned Network Upgrade}

The 200-ZP-1 pump-and-treat operations have changed groundwater flow directions at the south part of the WMA. The pump-and-treat operations are expected to continue until a record of decision is reached. Therefore, the drilling of an additional downgradient well on the south end of WMA TX-TY is planned in fiscal year 2003. Also, one additional well is planned for the east side of WMA TX-TY, south of well 299-W14-14 near the non-WAC compliant well 299-W14-6. 


\subsection{Rate and Direction of Groundwater Flow}

The rate of groundwater movement beneath WMA TX-TY is estimated from classical methods (Darcy equation) and from borehole tracer dilution tests. Groundwater flow rate indicates the maximum (conservative) flow rate for contaminants, whose movement through the aquifer is not retarded by mechanisms such as sorption or reaction.

\subsection{Flow Direction}

The direction of groundwater flow was estimated based on the gradient in the water-table elevations in the WMA TX-TY network monitoring wells. This approach assumes the aquifer is homogeneous. Because there is evidence that the aquifer is non-homogeneous, this limitation must be kept in mind when applying the gradient analysis approach to estimate flow direction. A general flow direction may be estimated over the WMA, but at any specific location, perturbations may occur in the local flow direction due to localized low or high permeability zones. Details of the changes in groundwater flow direction that occurred at WMA TX-TY in about 1998 are presented in Hodges and Chou (2001). Prior to 1997, groundwater flow was toward the northeast. In about 1998, the 200-ZP-1 pump-and-treat operation began to affect the groundwater flow direction beneath the southern part of WMA TX-TY.

Water-table elevations for the area around WMA TX-TY are illustrated in Figure 3.1, based on March and August 2001 water-level measurements. Contours on the water-table map indicate that general groundwater flow direction below WMA TX-TY changes with location. The general flow direction is toward the southeast below the northern part of the WMA and toward the south, or possibly the southsouthwest, below the southern part of the WMA. Groundwater beneath the southern part of the WMA is strongly influenced by the 200-ZP-1 pump-and-treat system.

Trend-surface analyses also have been applied to monitoring well water-level elevations at WMA TX-TY (Spane et al. 2001a,b). Trend surface analysis was done with commercially available software (WATER-VEL ${ }^{\mathrm{TM}}$ from In-Situ, Inc.). Water-level elevations from neighboring representative wells were used as input to calculate groundwater flow directions. The program uses a linear, two-dimensional trend surface (least squares) with randomly located water level elevation input data (Spane 2001a).

Analysis of May 1999 water-level data from wells 299-W10-17, 299-W10-18, 299-W14-12, 299-W15-12, and 299-W15-22 indicate a flow direction of 18 degrees east of south at wells 299-W10-26 and 299-W14-13. Analysis of May 2000 water-level data from wells 299-W14-5, 299-W14-6, 299-W14-14, 299-W15-40, and 299-W15-41 indicate a flow direction 16 degrees east of south at well 299-W15-41. The trend-surface derived flow direction for the former two wells at the northern part of the WMA is in good agreement with the flow direction inferred from the water-table map. The trend-surface derived flow direction for the southern well, 299-W15-41, is more easterly than the direction indicated on the water table map. This is because the trend-surface analysis did not include wells south or southwest of well 299-W15-41, which are influenced by the 200-ZP-1 pump-and-treat operations. 


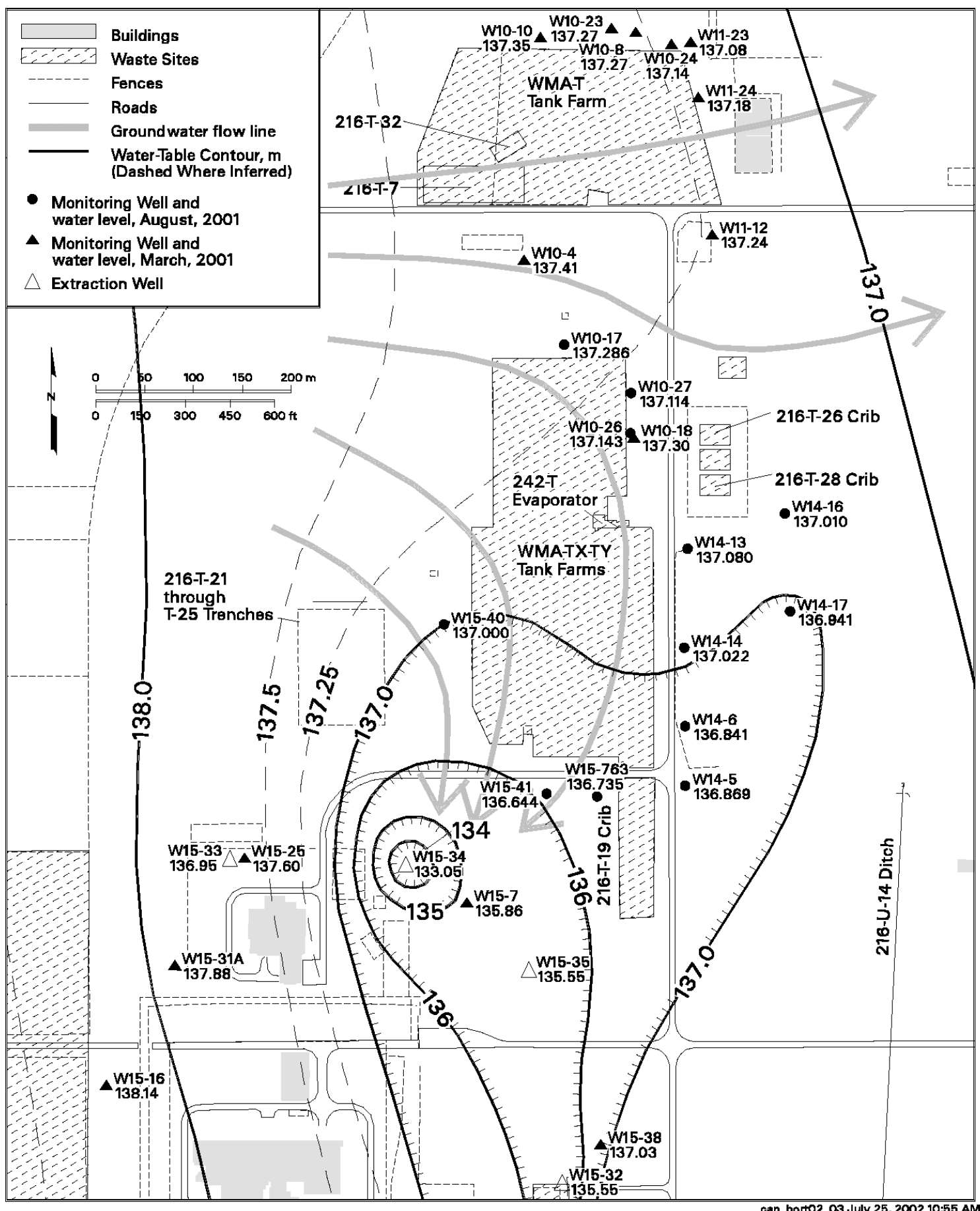

Figure 3.1. Water-Table Elevation Map for Waste Management Area TX-TY (March and August 2001 data) 


\subsection{Borehole Tracer Dilution and Tracer Pumpback Testing}

Borehole tracer dilution and tracer pumpback tests were conducted in three of the new RCRA monitoring wells at WMA TX-TY. These tests permitted some inferences about flow rate as well as aquifer homogeneity. After introduction of a bromide tracer into the boreholes, continuous measurements of the bromide concentrations were made using downhole bromide sensors and a data logger system. Five probes positioned $\sim 1$ meter apart were used to characterize the 4.8-meter screened interval of well 299-W15-41. Six equally spaced probes were used to characterize the 10.7-meter screened intervals in wells 299-W10-26 and 299-W14-13. These tests allowed direct observation of the effect of lateral groundwater flow through the screened interval of the wells, and, thus, provided an indication of the variability of flow through the screened intervals. Details of the test methods, computations, and the results are included in Spane et al. (2001a,b).

A significant feature of the tracer dilution test results is evidence for downward, vertical hydraulic gradients within the upper portion of the aquifer in wells 299-W10-26 and 299-W14-13. Vertical flow within these wells was first indicated by tracer-dilution studies and later confirmed by vertical tracer tests specifically designed to detect vertical flow within a borehole (Spane et al. 2001a). Downward vertical flow in these two wells was subsequently confirmed by electromagnetic flowmeter surveys (Waldrop and Pearson 2000). Data from all three tests are shown in Table 3.1.

Table 3.1. In-Well, Downward Vertical, Flow-Velocity Summary for Wells 299-W10-26 and 299-W-14-13 at Waste Management Area TX-TY (from Spane et al. 2001a)

\begin{tabular}{||c|c|c|c|c|c|c||}
\hline \multirow{2}{*}{ Test Well } & \multicolumn{2}{|c|}{ Tracer-Dilution Profile } & \multicolumn{2}{c|}{ Vertical Tracer Test ${ }^{(\mathrm{a})}$} & \multicolumn{2}{c||}{ Electromagnetic Flow-Meter Survey } \\
\cline { 2 - 7 } & Range (m/min) & Average (m/min) & Range (m/min) & Average (m/min) & Range (m/min) & Average (m/min) \\
\hline \hline 299-W10-26 & $0.002-0.004$ & 0.003 & $0.004-0.008$ & 0.005 & $0.003-0.006$ & 0.004 \\
\hline 299-W14-13 & $0.008-0.015$ & 0.011 & $0.013-0.014$ & 0.012 & $0.012-0.013$ & 0.012 \\
\hline $\begin{array}{l}\text { (a) In-well, vertical, flow-velocity range calculated using tracer peak arrival method for selected sensor depth, while the } \\
\text { average was determined using the center-of-mass technique. }\end{array}$ \\
\hline
\end{tabular}

The electromagnetic flow-meter surveys found that the depth of maximum downward flow was at 4.9 meters below the water table in well 299-W10-26 and at 5.6 meters below the water table in well 299-W14-13. Both wells have fairly homogeneous lithology throughout the screened interval (see Table 2.1) and the well development drawdown data do not indicate substantial variations in hydraulic conductivity.

Table 3.2 shows horizontal groundwater flow velocities determined from tracer pump back tests. These velocities are about an order of magnitude greater than the calculated velocities in Table 3.3 for wells 299-W10-26 and 299-W14-13. Both the measured and calculated velocities are about the same for well 299-W15-41. The vertical flow in wells 299-W10-26 and 299-W14-13 probably resulted in an overestimation of measured flow velocities. Also, the relatively rapid groundwater flow velocity for well 299-W15-41, located at the south end of WMA TX-TY, is likely a result of higher hydraulic gradients in the vicinity of the 200-ZP-1 pump-and-treat. 
Table 3.2. Results from Tracer-Dilution and Tracer-Pumpback Tests in Wells at Waste Management Area TX-TY (from Spane et al. 2001a,b)

\begin{tabular}{|c|c|c|c|}
\hline Well & Effective Porosity $^{(a)}$ & $\begin{array}{l}\text { Groundwater }^{(\mathrm{a})} \text { Flow } \\
\text { Velocity }(\mathrm{m} / \mathrm{d})\end{array}$ & $\begin{array}{l}\text { Average In-Well Flow } \\
\text { Velocities Average }^{(\mathrm{b})}\end{array}$ \\
\hline $299-\mathrm{W} 10-26^{(\mathrm{c})}$ & 0.010 & 0.124 & 0.086 \\
\hline $299-W 14-13^{(d)}$ & 0.009 & 0.191 & ND \\
\hline 299-W15-41 & 0.068 & 0.374 & 0.311 \\
\hline \multicolumn{4}{|c|}{ (a) Data from tracer pump back tests. } \\
\hline \multicolumn{4}{|c|}{ (b) Data from tracer dilution tests. } \\
\hline \multicolumn{4}{|c|}{ (c) Slight downward vertical flow, data uncertain. } \\
\hline \multicolumn{4}{|c|}{ (d) Strong downward vertical flow, data highly uncertain. } \\
\hline \multicolumn{4}{|c|}{ ND $=$ Not determined } \\
\hline
\end{tabular}

Table 3.3. Hydraulic Properties from Slug and Constant Rate Pumping Tests and Calculated Darcy Velocities at New Wells at Waste Management Area TX-TY

\begin{tabular}{|c|c|c|c|c|c|}
\hline Well & $\begin{array}{c}\text { Hydraulic }^{(\mathrm{a}, \mathrm{b})} \\
\text { Conductivity }(\mathrm{m} / \mathrm{d})\end{array}$ & $\begin{array}{c}\text { Hydraulic }^{(\mathrm{a}, \mathrm{c})} \\
\text { Conductivity }(\mathrm{m} / \mathrm{d})\end{array}$ & $\begin{array}{c}\text { Transmissivity }^{(\mathrm{a}, \mathrm{c})} \\
\left(\mathrm{m}^{2} / \mathrm{d}\right)\end{array}$ & $\begin{array}{l}\text { Specific }^{(\mathrm{a}, \mathrm{c})} \\
\text { Yield }\end{array}$ & $\begin{array}{l}\text { Calculated Flow Velocity } \\
(\mathrm{m} / \mathrm{d})\end{array}$ \\
\hline 299-W10-26 & "1.39-1.95 & 1.49 & 82 & 0.14 & $0.014^{(\mathrm{d})}$ \\
\hline 299-W14-13 & $1.66-2.43$ & 2.45 & 135 & 0.12 & $0.020^{(\mathrm{d})}$ \\
\hline 299-W14-14 & $1.97-2.64$ & ND & ND & ND & $0.026^{(\mathrm{e})}$ \\
\hline 299-W15-40 & $0.88-1.22$ & ND & ND & ND & $0.012^{(\mathrm{e})}$ \\
\hline 299-W15-41 & $14.2-19.9$ & 19.6 & 1130 & 0.12 & $0.29^{(\mathrm{f})}$ \\
\hline $\begin{array}{l}\text { (a) Data fror } \\
\text { (b) Slug test } \\
\text { (c) Constant } \\
\text { (d) Estimate } \\
\text { Specific } \\
\text { (e) Estimate } \\
\text { (f) Estimate } \\
\text { Table 3.2 } \\
\text { ND }=\text { Not det }\end{array}$ & $\begin{array}{l}\text { Spane et al. (2001a, b } \\
\text { ata. } \\
\text { ate pumping test data. } \\
\text { using maximum hydra } \\
\text { eld was used because } \\
\text { using maximum hydra } \\
\text { using maximum hydra } \\
\text { mined. }\end{array}$ & $\begin{array}{l}\text { lic conductivity valu } \\
\text { ownward flow in the } \\
\text { lic conductivity valu } \\
\text { lic conductivity valu }\end{array}$ & $\begin{array}{l}\text { gradient of } 0.001 \\
\text { ell resulted in unce } \\
\text { a gradient of } 0.001 \\
\text { a gradient of } 0.001\end{array}$ & $\begin{array}{l}\text { and specific } \\
\text { tain effective } \\
\text { and effective } \\
\text { and effective }\end{array}$ & $\begin{array}{l}\text { ield from this Table. } \\
\text { orosity. } \\
\text { orosity values of } 0.1 \text {. } \\
\text { porosity value from }\end{array}$ \\
\hline
\end{tabular}

The existence of vertical flow in a well does not necessarily reflect actual groundwater flow conditions within the surrounding aquifer, but its presence implies a flow gradient and has implications pertaining to the representativeness of groundwater samples collected from the wells. Thus, the vertical gradient detected along the eastern edge of WMA TX-TY may have an impact on contaminant distribution patterns in the area. The peak in technetium- 99 observed at a depth of 14.5 meters below the water table during drilling of well 299-W14-14 (see Section 4.1.2) may represent contaminants from within the WMA drawn deeper into the aquifer as a result of this gradient.

A second feature of the hydrologic test data is the suggestion of higher hydraulic conductivity in the middle and lower portions of the screened interval in well 299-W15-41. The data are shown in Table 3.4 (from Spane et al. 2001b). Also, development pumping data (see Table 2.2) indicates that the upper part of the screened interval in well 299-W15-763, located near well 299-W15-41, is less permeable than the lower part. Such hydraulic irregularities have been previously reported for the Ringold Formation at the north end of 200 West Area (Swanson 1994, pages 81 and 82; Lindsey and Mercer 1994, page 54). The 
Table 3.4. Tracer-Dilution Test Results for Well 299-W15-41 at Waste Management Area TX-TY (data from Spane et al. 2001b)

\begin{tabular}{|c|c||}
\hline \hline $\begin{array}{c}\text { Well Sensor/Depth Setting } \\
\text { (m, below top of casing) }\end{array}$ & $\begin{array}{c}\text { Calculated Well-Screen } \\
\text { Flow Velocity }(\mathrm{m} / \mathrm{d})\end{array}$ \\
\hline \hline 67.0 & 0.232 \\
\hline 67.9 & 0.257 \\
\hline 68.8 & 0.401 \\
\hline 69.7 & 0.382 \\
\hline 70.6 & 0.353 \\
\hline Average & 0.311 \\
\hline
\end{tabular}

apparent zone of lower hydraulic conductivity at the top of the screened intervals in wells along the southern part of the WMA may be the result of cementation or increased silt content in the upper part of the aquifer at this well. The geologist's log for well 299-W15-763 notes zones of iron oxide and silica cementation at the top and bottom of the screened interval in that well.

Taken as a whole, the geologist's logs, geophysical logs, development pumping data, and the hydrologic testing data all indicate heterogeneity in the aquifer properties within the screened intervals of several individual wells and among wells at WMA TX-TY. No widespread trends have been identified.

\subsection{Darcy Velocity}

The Darcy equation for estimating velocity (v) requires measurements of hydraulic conductivity (K), effective porosity $\left(\mathrm{n}_{\mathrm{e}}\right)$ and hydraulic gradient (i). The velocity is calculated from the following relationship:

$$
\mathrm{v}=\mathrm{Ki} / \mathrm{n}_{\mathrm{e}}
$$

For the WMA TX-TY assessment, new hydraulic conductivity data were obtained from slug tests and drawdown tests conducted in five new wells installed for this study. Effective porosity was determined using tracer drift and tracer pumpback test methods. Hydraulic properties determined for this study are discussed in detail by Spane et al. (2001a,b) and are presented in Tables 3.2 and 3.3.

Calculated Darcy velocities from tests in five new wells are shown in Table 3.3. There is approximately one order of magnitude variation in the data. Spane et al. (2001a) report vertical flow conditions in wells 299-W10-26 and 299-W14-13 so that the effective porosity from those field tests are questionable. Spane et al. (2001a) state that vertical flow in the wells likely introduces an underestimate of the effective porosities. For that reason, the Darcy velocity for wells 299-W10-26 and 299-W14-13 were calculated using the specific yield (Table 3.3) instead of the effective porosity. Using the specific yield results in a fairly consistent groundwater flow velocity of 0.014 to 0.026 meter per day except for well 299-W15-41, which is influenced by the 200-ZP-1 pump-and-treat operation. 


\subsection{Extent of Contamination}

This section presents discussions on the vertical and lateral extents of groundwater contamination at WMA TX-TY. Evaluation of the extent of contamination involves investigation of the type and concentration of RCRA-regulated contaminants in the groundwater, the depth distribution of contaminants, and the spatial extent of contamination. Monitoring results from new and existing wells, results of depth sampling during installation of new RCRA groundwater monitoring wells, and the comparison of groundwater chemistry in old wells and their adjacent replacement wells, provide new insights into the occurrence and nature of groundwater contamination attributable to WMA TX-TY.

\subsection{Depth Distribution}

Determining the vertical extent of dangerous-waste constituents within the uppermost aquifer is part of RCRA groundwater quality assessments. Hodges and Chou (2001) include plans for discrete depth sampling of both new and old wells at WMA TX-TY; however, a sampling device under development was not available in time to provide data for this report. A variety of data, however, including discrete depth sampling during drilling and comparison with adjacent wells that sample different parts of the aquifer provide important information about the depth distribution of contaminants.

\subsubsection{Conceptual Model Considerations}

Contaminants entering the surface of a homogeneous unconfined aquifer can be dispersed downward as well as laterally and longitudinally. The degree of vertical spreading varies depending on the dispersivities, hydraulic gradients, driving force (local recharge or net drainage to the aquifer), and the density of the waste fluid relative to the density of the groundwater. In the vicinity of WMA TX-TY, this is further complicated by the 200-ZP-1 pump-and treat operation, which may partly redistribute contaminants in the upper portion of the aquifer.

Departure from the theoretical depth distribution in a homogenous aquifer may occur depending on the nature of the aquifer host rock. As noted in Chapters 2 and 3, there are indications of heterogeneous conditions in the Ringold Formation in the area of WMA TX-TY. Limited data suggest that local, relatively impermeable zones exist at some wells particularly at wells 299-W10-27, 299-W14-18, and the lower part of 299-W15-763. In these areas, contaminants entering the aquifer from the vadose zone may be restricted to certain parts of the aquifer. Also, contaminants entering the WMA from upgradient sources may be concentrated in the relatively permeable parts of the aquifer. An additional complicating feature is the potential existence of lateral preferential flow paths creating deviations in predicted horizontal plume extent and flow direction. Finally, vertical flow within wells, such as that found at wells 299-W10-26 and 299-W14-13, may cause deviations in expected contaminant distribution. These kinds of local variations in lithology and flow system have not been incorporated into solute transport models for 200 West Area. Therefore, the best alternative is direct observation of vertical and lateral variations found in field data. Field observations made during the reporting period help delineate the vertical and lateral extent of contamination at WMA TX-TY. 


\subsubsection{Vertical Distribution Data}

Sampling at several discrete depths was conducted during drilling of well 299-W14-14 in 1998. Groundwater well 299-W14-14 was initially drilled through the lower mud unit of the Ringold Formation, with discrete sampling at $\sim 15$-meter intervals during drilling. Descriptions of the drilling and sampling of the well, as well as chemical results from the discrete level sampling, are presented in Horton and Hodges (1999) and are summarized in the following sections. In addition, samples of groundwater captured during air rotary drilling of wells 299-W14-15, 299-W14-16, 299-W14-18 (cable tool drilled), and 299-W15-765 provide useful information concerning possible vertical contaminant gradients within the aquifer. Finally, comparison of chemical data in new wells with data for the wells they are replacing provides data on chemical variation in the upper portion of the aquifer.

Individual wells with a sequence of vertically distributed samples and well pairs sampling different depths in the aquifer show that contaminants are not evenly distributed in the upper part of the unconfined aquifer at WMA TX-TY. In the one location with elevated chromium, the chromium maximum is located in a relatively deep part of the upper aquifer.

The information below concerning the depth distribution of contaminants is discussed relative to depth below the ground surface and not elevation. The surface elevation of all the wells discussed below is between 204.3 and 205.3 meters above mean sea level except for well 299-W15-763, which is at 202.2 meters above mean sea level. The 1-meter difference in elevation is much less than the depths of concentration differences observed in the wells and should not greatly affect the conclusions.

\subsubsection{Comparison of Chemical Data from New and Replaced Wells}

Replacement wells, when located immediately adjacent to an older, shallower well, offer an opportunity to look for vertical variation within the upper part of the aquifer. Three well pairs at WMA TX-TY are discussed in this section.

In each case discussed below, the old well and its replacement well are separated by only a few meters. In addition, in each case, the older well was last sampled when there was a fraction of a meter of water within the screened interval and the replacement well was sampled with a pump placed at least 3 meters below the water table within a 10.7-meter screened interval. Thus, the sample from the old well represents the top of the aquifer and the sample from the replacement well represents a composite of water taken over the length of the screened interval that includes both the water table and deeper parts of the aquifer.

Wells 299-W14-12 and 299-W14-13. Wells 299-W14-12 and 299-W14-13 are located 5 meters apart at the central part of the downgradient (east) side of WMA TX-TY. Well 299-W14-13 is the replacement well for well 299-W14-12 that went dry in early 1999. Well 299-W14-12 is the RCRA well that caused WMA TX-TY to remain in assessment monitoring according to the results in the Phase I groundwater quality assessment report (Hodges 1998). The last sampling of well 299-W14-12 took place in January 1999 and sampling of replacement well 299-W14-13 started in December 1998, allowing a sampling overlap between the two adjacent wells. The last samples collected from well 299-W14-12 
represent the top of the aquifer. The samples collected from well 299-W14-13 represent water throughout the screened interval, which extends from the water table to 10 meters below the water table. The pump intake is at 4.8 meters below the water table.

The concentrations of the dangerous waste constituent chromium in filtered samples from wells 299-W14-12 and 299-W14-13 are shown in Figure 4.1. The concentration of chromium in the last sample from well 299-W14-12 was about $45 \mu \mathrm{g} / \mathrm{L}$. This represented the concentration of chromium at the top of the aquifer in January 1999. The sample from replacement well 299-W14-13, taken about the same time, contained about $180 \mu \mathrm{g} / \mathrm{L}$ chromium. That sample represented the chromium concentration throughout the upper 10 meters of the aquifer. The conclusion is that the concentration of chromium is relatively small at the top of the aquifer and increases to a maximum at some depth below the water table. The $180 \mu \mathrm{g} / \mathrm{L}$ chromium value from well 299-W14-13 is a mixture of the low chromium-bearing water found at the water table with water containing higher chromium concentrations deeper in the aquifer.

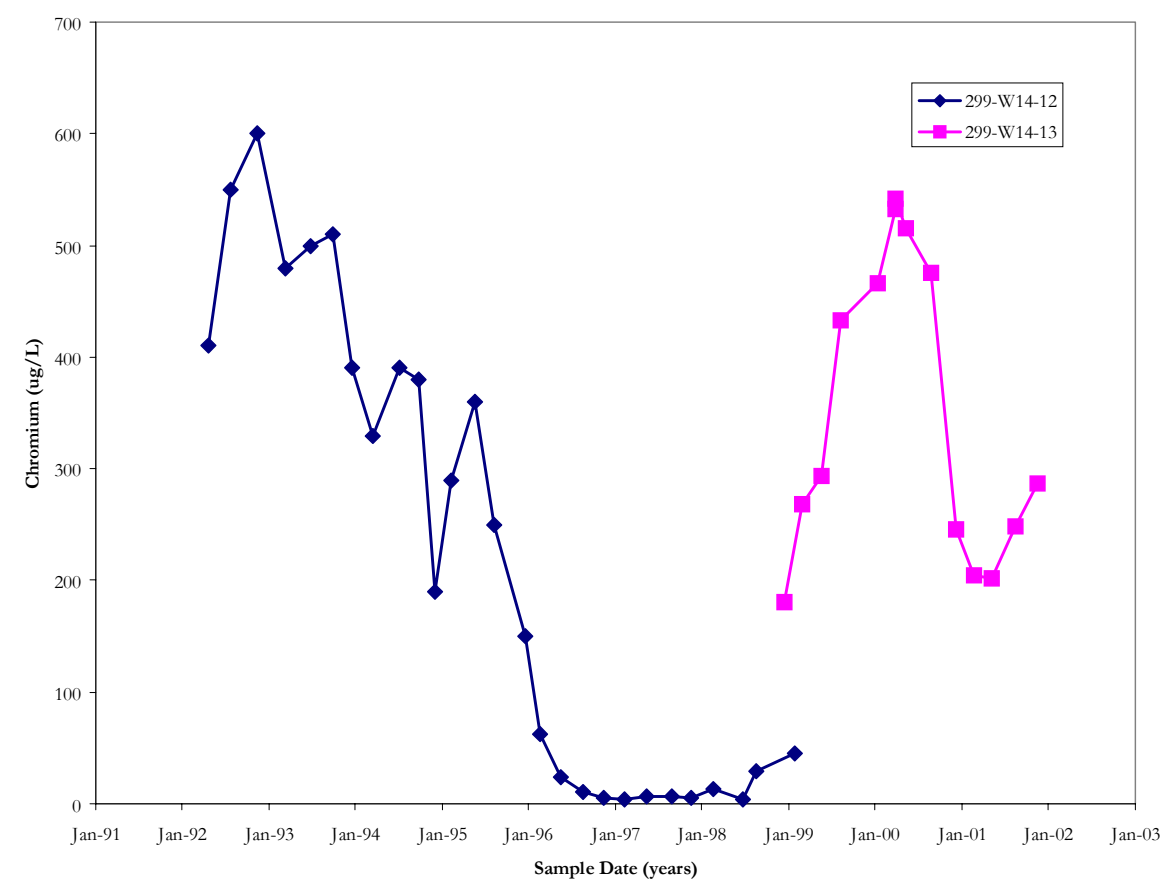

Figure 4.1. Chromium Concentrations in Filtered Samples from Wells 299-W14-12 and 299-W14-13 at Waste Management Area TX-TY

Chromium in the area of well 299-W14-12 began decreasing from a maximum of $\sim 600 \mu \mathrm{g} / \mathrm{L}$ in 1993 and continued to decrease until about February 1997. At that time, chromium began to increase and reached $46 \mu \mathrm{g} / \mathrm{L}$ in January 1999 when the well went dry. The increasing chromium trend continued in the replacement well until early 2000 when chromium concentrations climbed to $\sim 530 \mu \mathrm{g} / \mathrm{L}$. In early 2000 , chromium again began to decrease and reached about $200 \mu \mathrm{g} / \mathrm{L}$ in early 2001 . Since that time, chromium concentration had increased in well 299-W14-13 to about $287 \mu \mathrm{g} / \mathrm{L}$ at the end of the reporting period. 
Although not a RCRA-regulated constituent, the distribution of technetium-99 may have some bearing on the source for the dangerous waste constituent chromium. A trend plot for technetium-99 concentration in well 299-W14-12 and 299-W14-13 is shown in Figure 4.2. The concentration of technetium-99 in the last sample from well 299-W14-12 was about 6,000 pCi/L. This represented the concentration of technetium-99 at the top of the aquifer in January 1999. The sample from replacement well 299-W14-13, taken about the same time, contained about 2,500 pCi/L technetium-99. That sample represented the technetium-99 concentration throughout the upper 10 meters of the aquifer. The conclusion is that technetium- 99 exists at the top of the aquifer at about $6,000 \mathrm{pCi} / \mathrm{L}$ and the concentration decreases with depth in the aquifer. The $2,500 \mathrm{pCi} / \mathrm{L}$ technetium-99 value from well $299-\mathrm{W} 14-13$ is a mixture of the technetium-99 from the entire screened interval. Thus, the depth distribution for technetium-99, which is most likely from WMA TX-TY, is different from the depth distribution of chromium.

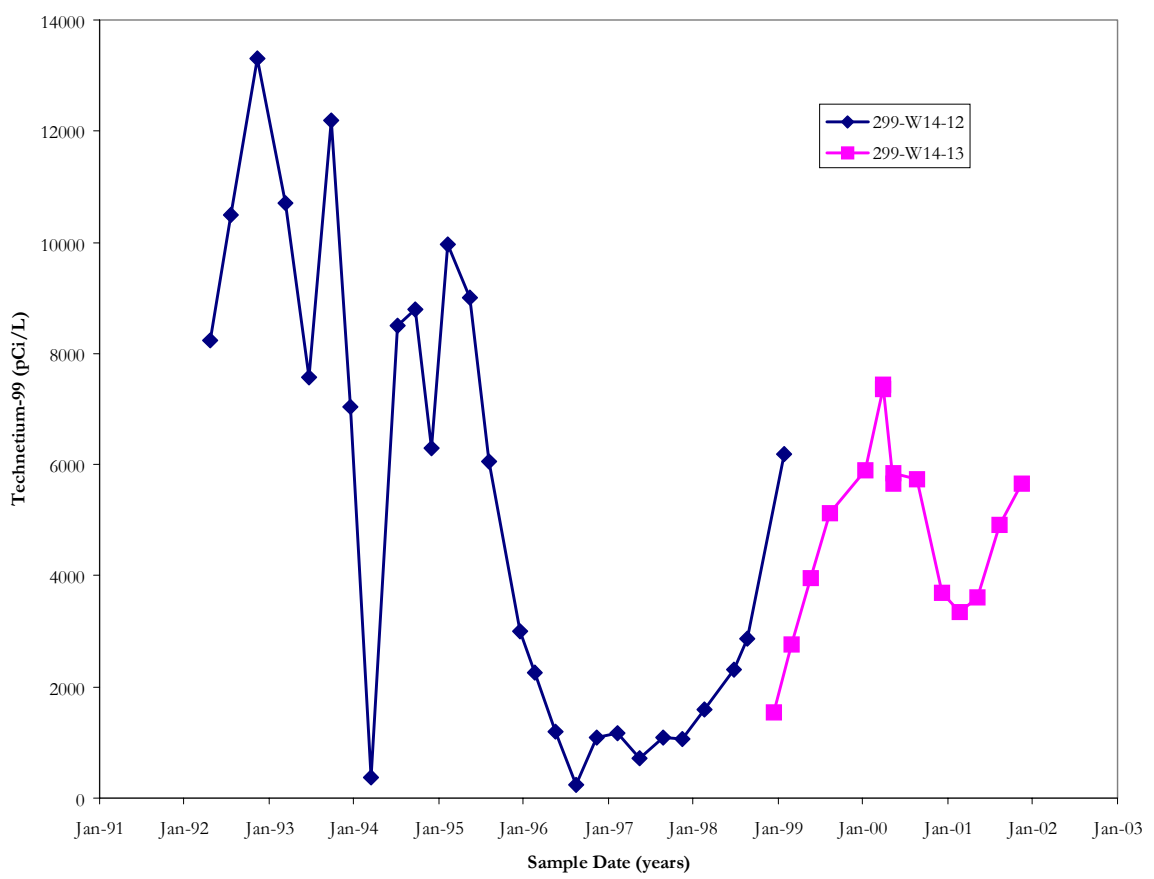

Figure 4.2. Technetium-99 Concentration in Wells 299-W14-12 and 299-W14-13 in Waste Management Area TX-TY

The technetium-99 concentrations through time show the same increasing and decreasing trends noted for the dangerous waste constituent chromium. If the chromium plume and the technetium-99 plume are from two separate sources, it is unclear why the two show parallel fluctuations in concentration through time. However, if the chromium and technetium-99 are from the same source and that source is WMA TX-TY, it is unclear how the two constituents became fractionated in the aquifer. Depth discrete sampling is planned for well 299-W14-13 to learn more about the vertical distribution of chromium and technetium-99 in the aquifer at well 299-W14-13. 
This is the only well pair in which chromium is elevated above regional background and chromium and technetium-99 show different distributions in the upper part of the aquifer.

Wells 299-W10-18 and 299-W10-26. Wells 299-W10-18 and 299-W10-26 are located $~ 5$ meters apart on the downgradient side of 241-TY tank farm. Well 299-W10-26 is the replacement well for well 299-W10-18 that went dry after last being sampled in August 1999. Sampling of the replacement well 299-W10-26 started in December 1998, allowing a sampling overlap of four samples between the two adjacent wells. The last samples collected from well 299-W10-18 represent the top of the aquifer. The samples collected from well 299-W10-26 represent water throughout the screened interval, which extends from 0.1 meter above the water table to 10.6 meters below the water table. The sampling pump intake is at 4.3 meters below the water table in well 299-W10-26.

Concentrations of chromium in filtered samples from both wells in the well pair are shown on Figure 4.3. Unlike at the well pair 299-W14-12 and 299-W14-13, chromium in the area of well 299-W10-26 appears to be evenly distributed through the upper part of the aquifer. Also current chromium values are significantly lower in this area and are on the order of the regional background.

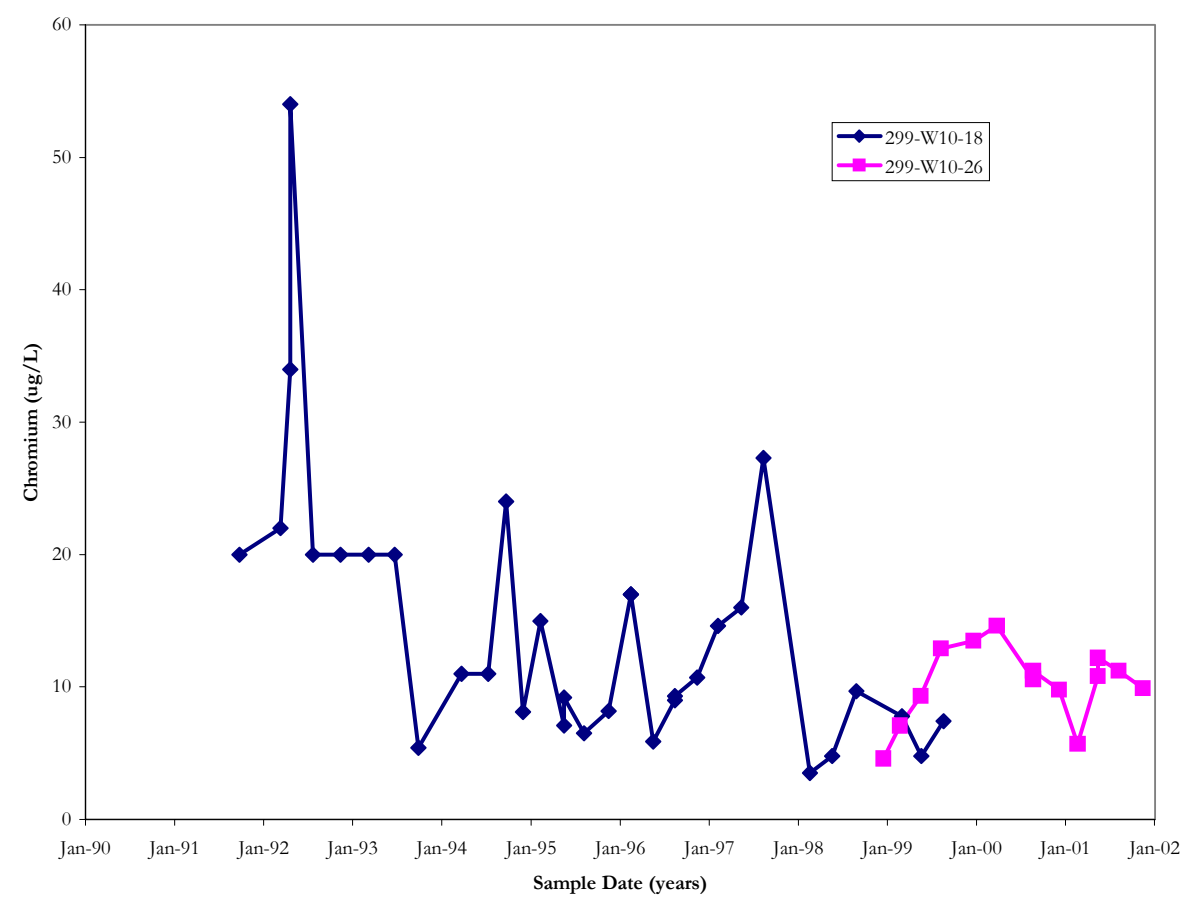

Figure 4.3. Chromium Concentrations in Filtered Samples from Wells 299-W10-18 and 299-W10-26

Wells 299-W15-765 and 299-W15-12. Wells 299-W15-12 and 299-W15-765 are located $\sim 4.5$ meters apart upgradient of the north part of the WMA. Well 299-W15-765 is the replacement well for well 299-W15-12 that went dry after last being sampled in March 2000. Sampling the replacement well 299-W15-765 began in November 2001 so that no overlap occurs among samples from the two wells. The last samples collected from well 299-W15-12 represents the top of the aquifer. The samples 
collected from well 299-W15-765 represent water throughout the screened interval that extends from the water table to 10.7 meters below the water table. The sampling pump intake is at 2.9 meters depth in the aquifer.

Concentrations of chromium in filtered groundwater samples from wells 299-W15-12 and 299-W15-765 are shown in Figure 4.4. Using the arguments for the distribution of chromium in the upper part of the aquifer that were used for the well pair 299-W14-12 and 299- W14-13, the distribution of chromium in wells 299-W15-12 and 299-W15-765 suggest that chromium may be present at higher at concentrations deeper in the aquifer in this location. However, the values are low and on the order of regional background.

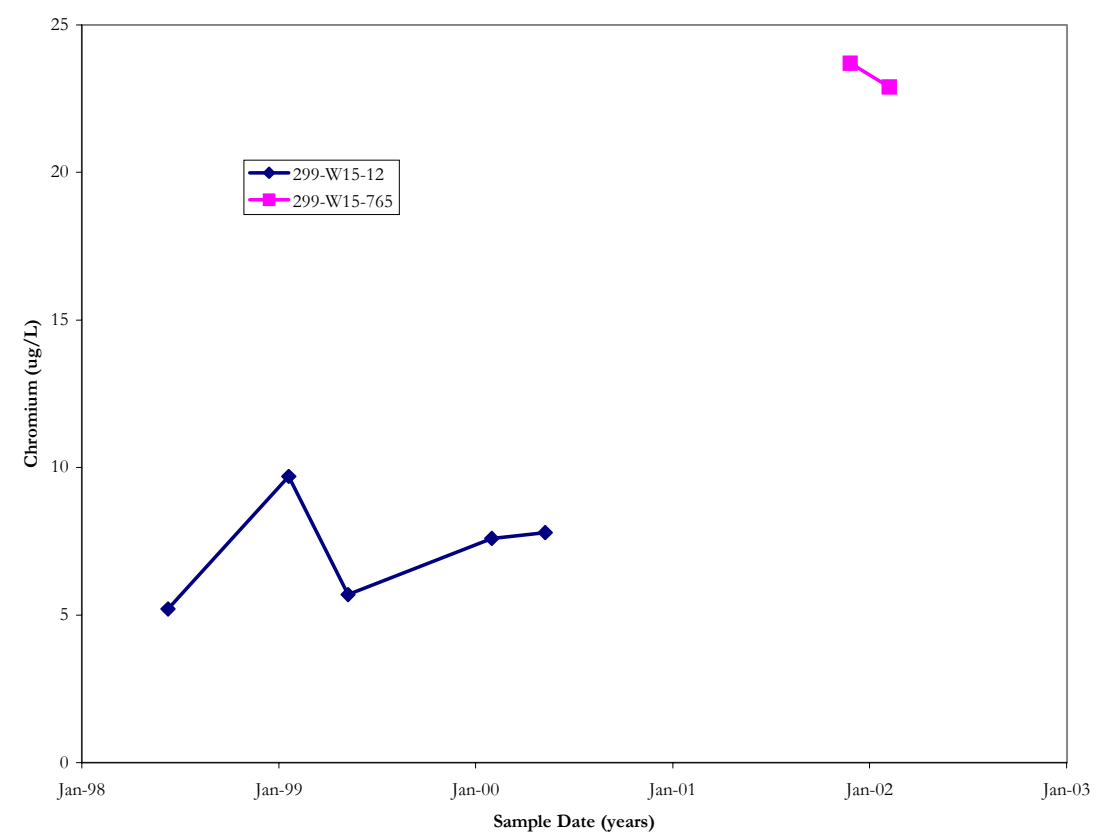

Figure 4.4. Chromium Concentrations in Filtered Samples from Wells 299-W15-12 and 299-W15-765 at Waste Management Area TX-TY

Alternatively, the relatively high chromium in well 299-W15-765 as compared with the top of the aquifer sample from well 299-W15-12 may result from the fact that the well was recently drilled.

Frequently, groundwater from new wells show high concentrations of some trace metals. This is particularly true if the well was drilled by cable tool methods. Well 299-W15-765 was drilled by air rotary and groundwater from the well does not have high concentrations of iron, manganese, nickel, or other metals. Thus, the chromium concentration in the well is probably not an artifact of drilling.

\subsubsection{Depth Discrete Groundwater Sampling at Well 299-W14-14}

Well 299-W14-14 was drilled through the lower mud unit of the Ringold Formation, prior to being completed as a top-of-the-aquifer monitoring well with a 10.7-meter long screen. An air rotary drilling 
method was used to advance the borehole. When the desired depths were reached, the drill string was replaced with a submersible pump-and-packer assembly consisting of a 1.5-meter length of slotted PVC that served as a temporary screen. The inflatable packer was used to isolate standing water in the drive casing from the water pumped to the surface. Water was purged until indicator parameters $(\mathrm{pH}$, specific conductance, and temperature) were stabilized. Purge volumes were on the order of 400 liters. The water samples were filtered in the field to remove particulates.

Results from the pump-and-packer sample depths are shown in Table 4.1. The maximum concentration of carbon tetrachloride was found at about 40 meters below the water table. Detectable contamination extends through the unconfined aquifer and beneath the lower mud unit. (The lower mud unit extends from 56 to 67 meters below the water table in well 299-W14-14.) The concentration of carbon tetrachloride in the water samples obtained from the lower mud unit is less than concentrations in samples collected above and below the unit. However, an increase in the concentration of carbon tetrachloride in the deepest sample allows that that concentrations may continue to increase with depth below the lower mud unit at well 299-W14-14. The carbon tetrachloride encountered at depth in well 299-W14-14 is probably part of the regional plume in the area of WMA TX-TY.

Table 4.1. Discrete Depth Sampling Results from Well 299-W14-14

\begin{tabular}{|c|c|c|}
\hline $\begin{array}{l}\text { Depth Below } \\
\text { Water Table } \\
\text { (m) }\end{array}$ & $\begin{array}{l}\text { Specific Conductance } \\
\qquad(\mu \mathrm{S} / \mathrm{cm})\end{array}$ & $\begin{array}{c}\text { Carbon Tetrachloride } \\
(\mu \mathrm{g} / \mathrm{L})\end{array}$ \\
\hline \multicolumn{3}{|l|}{$4.3^{(\mathrm{a})}$} \\
\hline 14.51 & 687 & 180 \\
\hline 30.05 & 382 & 380 \\
\hline 39.81 & 467 & 920 \\
\hline 56.88 & 541 & 380 \\
\hline $68.46^{(\mathrm{b})}$ & 430 & 590 \\
\hline \multicolumn{3}{|c|}{$\begin{array}{l}\text { (a) Sample from screened interval after well completion. } \\
\text { (b) Sample from below Ringold lower mud unit. }\end{array}$} \\
\hline
\end{tabular}

\subsubsection{Sampling During Drilling}

Sampling of water brought to the surface during air rotary drilling can give an indication of vertical variations within the aquifer (Johnson and Chou 2001). During drilling in calendar year 2000 and 2001, limited sampling during drilling was completed at five wells in WMA TX-TY. The results from one well (well 299-W14-17) were inconclusive. The results from the other four wells are discussed below.

Well 299-W14-15. In August 2000, three groundwater samples were separated from airlifted slurry during drilling of downgradient, point-of-compliance well 299-W14-15, east of WMA TX-TY. The samples were filtered using a peristaltic pump and a $0.45-\mu \mathrm{m}$ filter cartridge prior to analysis in the field. Specific conductance and nitrate concentrations were measured. Specific conductance results as a function of depth below the water table are shown in Table 4.2. 
Table 4.2. Analytical Results for Groundwater Samples Taken During Drilling of New Wells at Waste Management Area TX-TY

\begin{tabular}{||c|c|c||}
\hline \hline Well & $\begin{array}{c}\text { Depth Below Water } \\
\text { Table }(\mathrm{m})\end{array}$ & $\begin{array}{c}\text { Specific Conductance } \\
(\mu \mathrm{S} / \mathrm{cm})\end{array}$ \\
\hline \hline 299-W14-15 & 3.4 & 540 \\
\hline & 5.1 & 556 \\
\hline & 9.6 & 571 \\
\hline 299-W14-16 & 3.1 & 304 \\
\hline & 6.1 & 403 \\
\hline & 9.1 & 533 \\
\hline & 13.1 & 680 \\
\hline
\end{tabular}

Between the depths of 3.4 to 9.6 meters below the water table, specific conductance increased from 540 to $571 \mu \mathrm{S} / \mathrm{cm}$. All intervals sampled are within the current screened interval. During the first routine sampling of this well in December 2000, the measured specific conductance value was $586 \mu \mathrm{S} / \mathrm{cm}$. (Sampling pump intake is at about 2.2 meters below the water table.) Subsequent routine sampling during four quarters of 2001 yielded specific conductance values between 571 and $595 \mu \mathrm{S} / \mathrm{cm}$. The specific conductance in well 299-W14-15 has been related to the regional nitrate plume in the area (Horton 2002b).

Well 299-W14-16. Four groundwater samples were collected in October and November of 2000 from slurry samples air lifted during the drilling of downgradient well 299-W14-16, east of WMA TX-TY. The samples were filtered using a peristaltic pump and a $0.45-\mu \mathrm{m}$ filter cartridge prior to analysis in the field. Specific conductance and nitrate concentrations were measured. Specific conductance results as a function of depth below the water table are shown in Table 4.2. Water, added to the borehole to facilitate drilling just above the water table, may have diluted the results from the shallowest sample.

Analytical results show a continuous increase in specific conductance from 304 to $680 \mu \mathrm{S} / \mathrm{cm}$ between 3 and 13.1 meters beneath the water table. The highest values are at a depth of 13.1 meters, about 2.3 meters below the bottom of the 10.7-meter screen installed in the well. (The screened interval is 0.1 to 10.8 meters below the water table.) Groundwater from the first year of quarterly, routine sampling of this well yielded specific conductance values between 574 and $611 \mu \mathrm{S} / \mathrm{cm}$. These data suggest that a greater proportion of water in the routine samples is contributed from the lower portion of the screened interval than from the upper portion of the interval indicating that the aquifer in the lower portion of the screened interval is more permeable than that in the upper portion. This is substantiated by the geophysical log and sieve analyses that indicate less silt in the formation around the lower part of the screened interval relative to the upper part of the screened interval.

Well 299-W14-18. Two groundwater samples were collected in October 2001, during drilling of well 299-W14-18 downgradient of WMA TX-TY. The samples were collected at the top of the aquifer 
and at total drill depth. The samples were transported to laboratories at PNNL. In the laboratory, the samples were filtered and analyzed for specific conductivity using the laboratory's standard operating procedures (AGG-SST-VZC) ${ }^{(a)}$ Analysis results are shown in Table 4.3.

Table 4.3. Specific Conductance and $\mathrm{pH}$ for Samples from Wells 299-W14-18 and 299-W15-765 at Waste Management Area TX-TY

\begin{tabular}{||c|c|c||}
\hline $\begin{array}{c}\text { Well Name and Depth (meters } \\
\text { below the water table) }\end{array}$ & $\mathrm{pH}$ & $\begin{array}{c}\text { Specific Conductivity } \\
(\mu \mathrm{S} / \mathrm{cm})\end{array}$ \\
\hline \hline 299-W14-18 \\
\hline At the water table & 7.65 & 543 \\
\hline 12.6 & 7.61 & 269 \\
\hline 299-W15-765 & 7.39 & 352 \\
\hline 5.5 & 7.46 & 674 \\
\hline 13.8 &
\end{tabular}

The specific conductivity from the water-table sample in well 299-W14-18 is about twice as high as that in the 12.6-meter sample. Two routine groundwater samples collected subsequent to drilling had specific conductivity values of 566 and $602 \mu \mathrm{S} / \mathrm{cm}$. The specific conductance value for the deep sample from well 299-W14-18 is unreasonable low and is lower than reported values for uncontaminated, sitewide background (DOE/RL 1992). Specific conductance values from routine, quarterly sampling are generally between about 500 and $700 \mu \mathrm{S} / \mathrm{cm}$ for most wells in the WMA TX-TY network.

Well 299-W15-765. Two groundwater samples were collected in September 2001, during drilling of well 299-W15-765 upgradient of WMA TX-TY. The samples were collected from 5.5 and 13.8 meters below the water table. The samples were transported to laboratories at PNNL. In the laboratory, the samples were filtered and analyzed for specific conductivity and anions using the laboratory's standard operating procedures (AGG-SST-VZC). ${ }^{\text {(a) }}$ Analysis results are shown in Table 4.3.

The specific conductivity from the shallower sample is about one-half the value from the deeper sample. Two routine groundwater samples collected subsequent to drilling had specific conductivity values of 691 and $687 \mu \mathrm{S} / \mathrm{cm}$, which are similar to the deeper sample collected during drilling. This indicates that water from deeper in the aquifer contributes more to the routine samples than does water from near the water table. The pump intake in this well is 2.9 meters below the water table.

\subsection{Geographic Distribution}

This section summarizes the areal distribution of the dangerous waste constituents in groundwater at WMA TX-TY. Chromium is the only RCRA-regulated constituent found that may have its origin from

(a) AGG-SST-VZC. Applied Geology and Geochemistry Group Procedures for Single-Shell Tank Vadose Zone Characterization, Pacific Northwest National Laboratory, Richland, Washington. 
WMA TX-TY. (Carbon tetrachloride is also found at WMA TX-TY, but its origin is from past-practice activities associated with the Plutonium Finishing Plant.)

\subsubsection{Chromium Upgradient of WMA TX-TY}

Wells 299-W15-40 and 299-W15-765 are the current upgradient wells at WMA TX-TY. Figure 4.5 shows the levels of chromium in these wells. In addition, well 299-W15-22 was used as an upgradient well from September 1991 to August 1998 when it went dry and well 299-W15-12 was used as an upgradient well from 1988 to May 2000 when it went dry. Data from those wells also are shown in Figure 4.5. Current chromium concentrations upgradient of WMA TX-TY are below the drinking water standard of $100 \mu \mathrm{g} / \mathrm{L}$ and between 5 and $25 \mu \mathrm{g} / \mathrm{L}$.

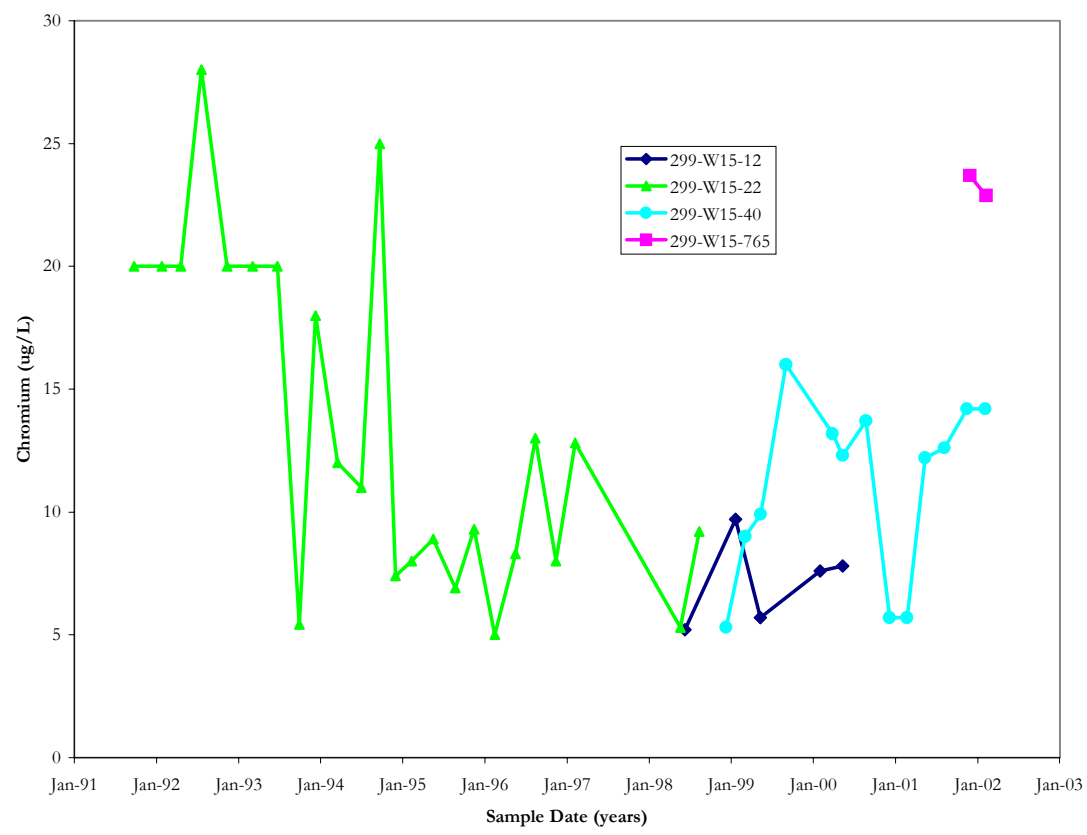

Figure 4.5. Chromium Concentrations in Upgradient Wells at Waste Management Area TX-TY

\subsubsection{Chromium Downgradient of Waste Management Area TX-TY}

Contaminant levels for chromium were high in well 299-W14-12 when RCRA monitoring began in April of 1992 (Caggiano and Chou 1993). Contaminant levels peaked in late 1992 and then declined until 1997, the steepest decline corresponding to the rapid drop in the water table after 1995. Contaminant concentrations reached their minimum values in the 1996 to 1997 time period and began to increase in 1998, at about the time of the change in groundwater flow direction from northeast to southeast. Concentration levels continued to increase until the well became unsamplable in January 1999. The contaminant history for chromium in well 299-W14-12 is shown in Figure 4.1. The upward trend observed in well 299-W14-12 continued in well 299-W14-13, with the offsets discussed above in Section 4.1.2.1 (see Figure 4.1). 
Figure 4.6 shows a plume map for the dangerous waste constituent chromium at the end of the reporting period. The figure shows that, at the end of the reporting period, chromium was detected in one downgradient well (299-W14-13) above the drinking water standard of $100 \mu \mathrm{g} / \mathrm{L}$. The nearest potential source for the chromium is WMA TX-TY.

The plume east of WMA TX-TY was moving toward the northeast prior to the most recent shift in flow direction in the late 1990s. The decline in chromium concentration up until 1998 (see Figure 4.1) could be the result of a declining source term or a lateral shift in the bulk of the plume away from well 299-W14-12.

The increasing chromium concentrations since 1998 may be attributed to the latest change in groundwater flow direction. Comparison of older water-table maps shows that groundwater flow direction changed from northeast to southeast at the eastern part of WMA TX-TY in the 1997 to 1998 time frame. If the main portion of the plume was to the north of well 299-W14-12 prior to 1998, the change in flow direction would have caused the plume to drift south across the well. Alternatively, it is possible that a new contaminant plume is migrating southeast from the 241-TY tank farm. Assuming a groundwater flow rate of $0.2 \mathrm{~m} / \mathrm{d}$ (see Section 3.3), a plume would take about 400 days to travel the $\sim 80$ meters from the fence line at 241-TY tank farm to well 299-W14-13. However, high levels of chromium have not been observed in wells 299-W10-26, 299-W10-18 (before it went dry), or 299-W14-18. 


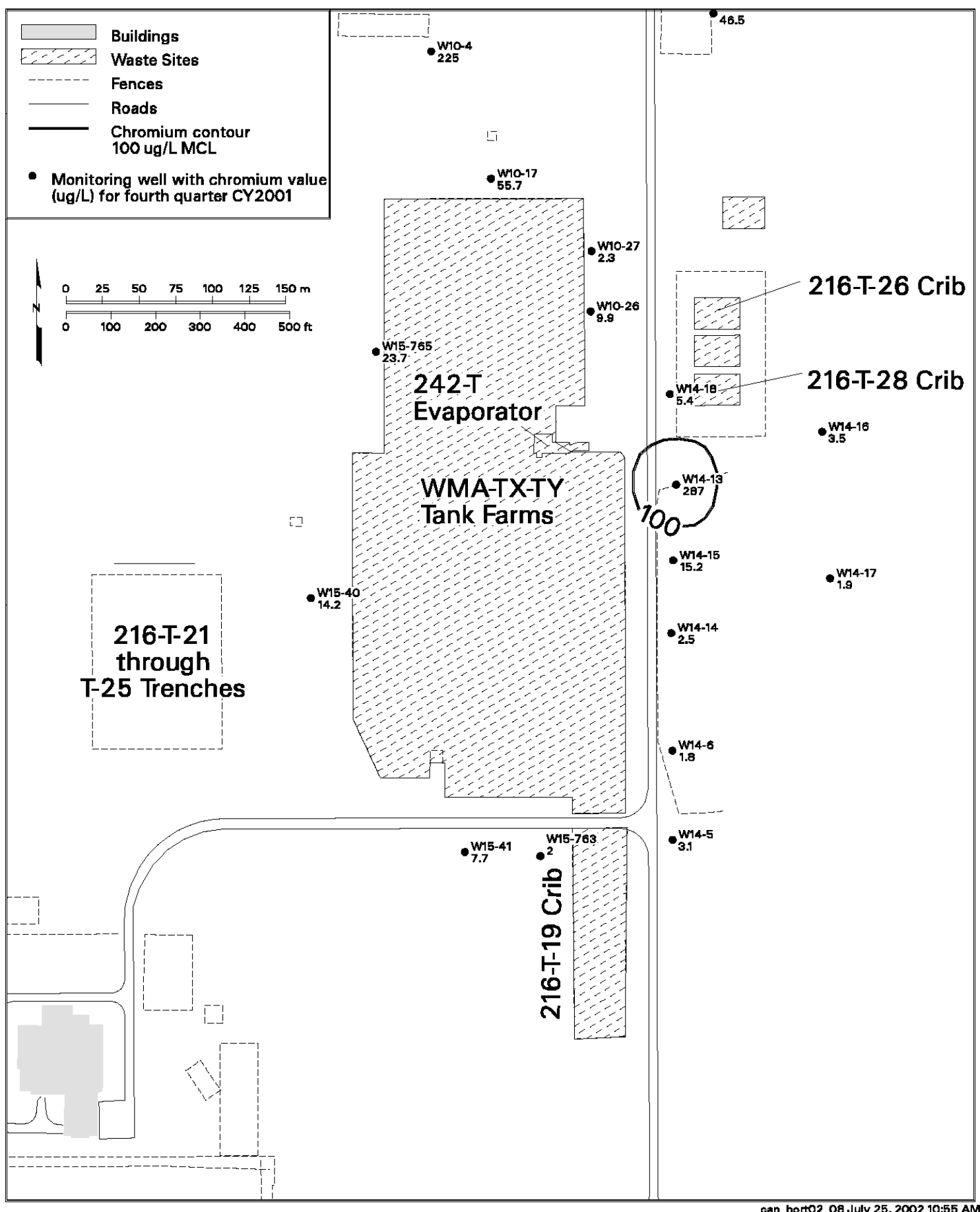

Figure 4.6. Chromium Plume Map at Waste Management Area TX-TY for the Fourth Quarter of Calendar Year 2001 


\subsection{Maximum Contaminant Concentrations}

This section presents a brief discussion on the maximum contaminant levels for dangerous waste constituents encountered at WMA TX-TY during the reporting period.

Table 5.1 shows the maximum concentrations detected for the dangerous waste constituents chromium and carbon tetrachloride in each well included in the monitoring network for the period January 1, 1998, to December 31, 2001. Samples collected during drilling of new wells were not included in Table 5.1. Only filtered $(0.45 \mu \mathrm{m})$ chromium results were included in the summary. The values for carbon tetrachloride are all based on unfiltered samples. The last column shows the highest maximum contaminant concentration (values in bold type) divided by the applicable maximum contaminant level or drinking water standard. The ratio is referred to as the relative hazard index for purposes of this report.

The highest relative hazard index at WMA TX-TY is a result of carbon tetrachloride. The high relative hazard index, a value of $560(2,800 \mu \mathrm{g} / \mathrm{L})$ for well 299-W15-40 at WMA TX-TY, is believed to be the result of disposal of carbon tetrachloride in cribs and trenches associated with the Plutonium Finishing Plant. Therefore, it is not associated with contamination from WMA TX-TY.

The highest relative hazard index for chromium is 5.4 resulting from $542 \mu \mathrm{g} / \mathrm{L}$ in well $299-\mathrm{W} 14-13$. Chromium is the only dangerous-waste constituent identified at WMA TX-TY with a source likely attributed to the WMA. 
Table 5.1. Maximum Contaminant Concentrations for Groundwater Samples Collected from Waste Management Area TX-TY Network Wells (January 1998 to December 2001)

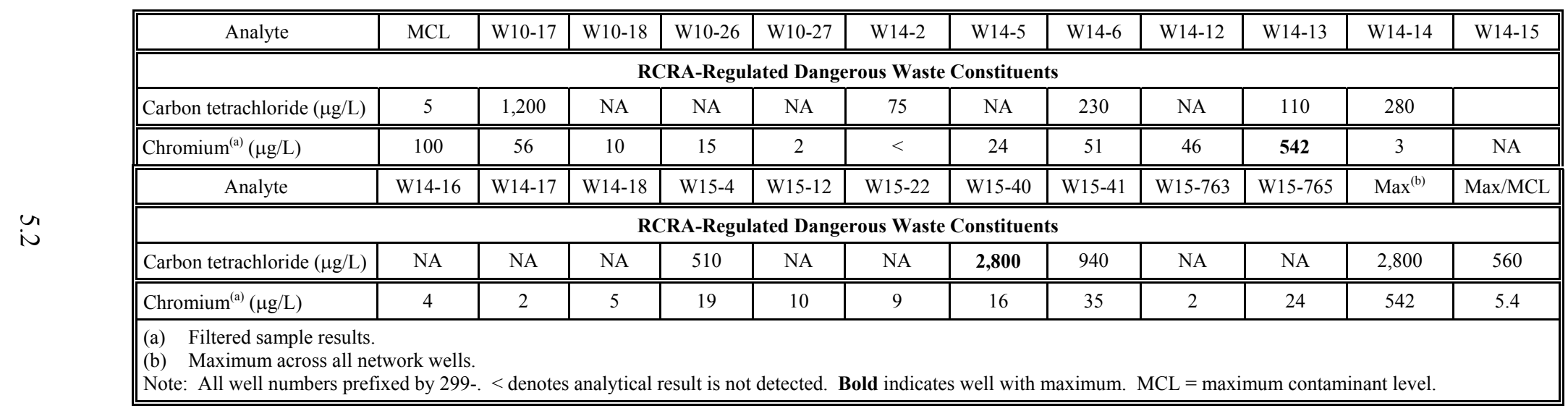




\subsection{Conceptual Model}

An updated conceptual model of processes controlling the extent of contaminant distribution and its rate of movement in groundwater in the vicinity of WMA TX-TY must include the following:

- Complex contaminant plume interactions and concentration-time patterns are due to disposal history and changing flow directions induced by both pump and treat operations and the long-term decline in the water table.

- Flow directions vary beneath WMA TX-TY from southeastward in the north to southward and southwestward in the south

- Vertical and horizontal variations in lithology result in variations in aquifer permeability, which can influence the distribution of contaminants.

- Past-practice disposal of large volumes of wastewater upgradient of the WMAs accounts for most of the deeply distributed contaminants (carbon tetrachloride).

- Downward, vertical hydraulic gradients exist on the east side of WMA TX-TY, which may influence the distribution of contaminants.

- The 200-ZP-1 pump-and-treat operation, south of the WMA, has altered groundwater flow.

Additional details concerning these processes and proposed explanations for observed contaminant distribution patterns are discussed in the following sections.

\subsection{Aquifer Properties}

The permeability of the upper portion of the aquifer at WMA TX-TY is variable. This variability is attributed to changes in lithology, including silt content and cementation, within the aquifer sediment. These lithology changes and the resulting permeability changes are laterally variable. In some wells, such as 299-W10-27, the entire screened interval appears to be in a low permeability formation. In other wells, such as adjacent well 299-W10-26, the screened interval is in a relatively permeable zone. In still other wells, such as well 299-W15-763, permeability seems to change within the screened interval. Changes in permeability may effect both contaminant distribution and the composition of water sampled from wells (i.e., different amounts of water from permeable and non-permeable zones).

\subsection{Contaminants at Waste Management Area TX-TY}

The dangerous waste constituent chromium, which is likely related to tank waste has been detected in well 299-W14-13, along the eastern margin of the WMA, above the maximum contaminant level. Tank waste has been present at this location since the inception of RCRA groundwater monitoring in 1992. 
After the change in groundwater flow direction in 1997 to 1998, the existing chromium plume would have migrated laterally toward the east or southeast, resulting in the subsequent increase of contaminant concentration in well 299-W14-13. Assuming a groundwater flow rate of 0.25 meters per day, contamination should have reached well 299-W14-17, located $~ 125$ meters downgradient of well 299-W14-13, $\sim 21$ months after the latest shift in flow direction. At the end of 2001, chromium concentration was low in well 299-W14-17 at about $2 \mu \mathrm{g} / \mathrm{L}$. Thus, the chromium seen in well 299-W14-13 has migrated slower than 0.25 meters per day (due possibly to lithology changes) and remains upgradient or it is diverted from the well.

Vadose zone characterization and monitoring, at the 241-TX and TY tank farms with wireline geophysical methods, have shown the distribution of near surface radionuclide contamination, which is probably the result of spills associated with tank farm operations, and deeper radionuclide contamination, resulting from tank leaks (GJO-97-30-TAR; GJO-97-13-TAR). It is assumed that chromium is also present. Geophysical monitoring also has indicated that contaminants continue to move in the vadose zone at some locations. Also, drilling results at WMA S-SX and various modeling studies (Johnson and Chou 2001) indicate that major vadose plumes within the tank farms may contribute to groundwater contamination for decades. Thus, it is likely that any vadose zone sources in WMA TX-TY that are responsible for the chromium contamination detected east of the WMA are still active. 


\subsection{Conclusions}

Additional assessment characterization and monitoring activities were conducted to evaluate the rate, extent, and concentration of dangerous waste contaminants in groundwater beneath WMA TX-TY. Installation of additional groundwater monitoring wells, hydrologic testing, and sampling and analysis (both vertically and spatially) provided new information, which resulted in the following conclusions.

\subsection{Rate and Extent of Contaminant Migration}

Observations made during the drilling of wells at WMA TX-TY, suggest variability in lithologic properties within the screened intervals of both individual wells and among wells. The lithologic changes are reflected in variabilities in hydraulic properties. Hydrologic testing was conducted on newly installed wells. Associated hydraulic conductivities from both drawdown and slug tests, and effective porosities from selected tracer tests (borehole dilution tests), were determined for this assessment. Resulting hydraulic conductivity values vary significantly across the WMA, with the highest values occurring at the south end of WMA TX-TY near the 200-ZP-1 pump-and-treat operations.

The groundwater flow rate was found to be on the order of 0.012 to 0.026 meters per day except in the southern part of the WMA, which is affected by the 200-ZP-1 pump-and-treat operation. There, the groundwater flow rate was found to be 0.29 meter per day.

Sampling during drilling and comparisons between adjacent wells indicates considerable chemical variability within the upper portion (upper 10 to 12 meters) of the aquifer at WMA TX-TY. The variability is a result of multiple contaminant sources and possibly vertical hydraulic gradients and variable hydraulic conductivity within screened intervals.

Chromium and carbon tetrachloride are the only dangerous-waste constituents found in the groundwater at WMA TX-TY. Carbon tetrachloride is attributed to past-practice operations at the Plutonium Finishing Plant. Chromium is a mobile tank constituent and is attributed to the WMA. However, the relatively deep occurrence of chromium in the aquifer and its apparent fractionation from technetium-99, a non-RCRA regulated constituent found at the top of the aquifer, allows the possibility that chromium is from a non-WMA TX-TY source.

\subsection{Concentration of Contaminants}

The maximum concentration of chromium found at WMA TX-TY during January 1998 through December 2001 was $542 \mu \mathrm{g} / \mathrm{L}$ in well 299-W14-13.

\subsection{Well Network}

Lateral downgradient coverage is adequate along the northern and central portions of the eastern boundary of WMA TX-TY. However, along the southeastern and southern boundaries, there is a need for 
additional wells. One new well is planned for the southwestern corner of the WMA to serve as a downgradient well in response to a southerly flow direction imposed by the 200-ZP-1 pump-and-treat operation. Another new well is planned at the southern part of the eastern boundary of the WMA, south of well 299-W14-14, where no RCRA-compliant wells exist. These wells are scheduled for installation in fiscal year 2003 . 


\subsection{References}

40 CFR 265, Code of Federal Regulations, Title 40, Part 265. Interim Status Standards for Owners and Operators of Hazardous Waste Treatment, Storage, and Disposal Facilities.

Caggiano, J. A. and C. J. Chou. 1993. Interim-Status Groundwater Quality Assessment Plan for the Single-Shell Tank Waste Management Areas T and TX-TY. WHC-SD-EN-AP-132, Westinghouse Hanford Company, Richland, Washington.

DOE/RL. 1992. Hanford Site Groundwater Background. DOE/RL-92-23, U.S. Department of Energy, Richland Operations Office, Richland, Washington.

DOE/RL. 2000. Phase I RCRA Facility Investigation/Corrective Measures Study Work Plan for SingleShell Tank Waste Management Areas. DOE/RL-99-36, Rev. 1, U.S. Department of Energy, Richland Operations Office, Richland, Washington.

GJO-97-13-TAR, GJO-HAN-11. Vadose Zone Characterization Project at the Hanford Tank Farms. TX Tank Farm Report. U.S. Department of Energy, Grand Junction Office, Grand Junction, Colorado.

GJO-97-30-TAR, GJO-HAN-16. Vadose Zone Characterization Project at the Hanford Tank Farms. TY Tank Farm Report. U.S. Department of Energy, Grand Junction Office, Grand Junction, Colorado.

Hartman, M. J., L. F. Morasch, and W. D. Webber (eds.). 2002. Hanford Groundwater Monitoring for Fiscal Year 2001. PNNL-13788, Pacific Northwest National Laboratory, Richland, Washington.

Hodges, F. N. 1998. Results of Phase I Groundwater Quality Assessment for Single-Shell Tank Waste Management Area T and TX-TY at the Hanford Site. PNNL-11809, Pacific Northwest National Laboratory, Richland, Washington.

Hodges, F. N. and C. J. Chou. 2001. RCRA Assessment Plan for Single-Shell Tank Waste Management Area TX-TY at the Hanford Site. PNNL-12072, Pacific Northwest National Laboratory, Richland, Washington.

Horton, D. G. and F. N. Hodges. 1999. Borehole Data Package for 1998 Wells Installed at Single-Shell Tank Waste Management Area TX-TY. PNNL-12124, Pacific Northwest National Laboratory, Richland, Washington.

Horton, D. G. and F. N. Hodges. 2000. Borehole Data Package for Well 299-W15-40 at Single-Shell Tank Waste Management Area TX-TY. PNNL-13201, Pacific Northwest National Laboratory, Richland, Washington. 
Horton, D. G. and F. N. Hodges. 2001. Borehole Data Package for Calendar Year 2000-2001 RCRA Wells at Single-Shell Tank Waste Management Area TX-TY. PNNL-13591, Pacific Northwest National Laboratory, Richland, Washington.

Horton, D. G. 2002a. Borehole Data Package for Calendar Year 2001 RCRA Wells at Single-Shell Tank Waste Management Area TX-TY. PNNL-13826, Pacific Northwest National Laboratory, Richland, Washington.

Horton, D. G. 2002b. Groundwater Conditions at Single-Shell Tank Waste Management Area TX-TY (January 1998 through December 2001). PNNL-14004, Pacific Northwest National Laboratory, Richland, Washington.

Johnson, V. G. and C. J. Chou. 2001. RCRA Groundwater Quality Assessment Report for Waste Management Area S-SX (November 1997 through April 2000). PNNL-12114, Pacific Northwest National Laboratory, Richland, Washington.

Lindsey, K. A. and R. B. Mercer. 1994. Geologic Setting of the Low-Level Burial Grounds. WHC-SDEN-TI-290, Westinghouse Hanford Company, Richland, Washington.

RCRA - Resource Conservation and Recovery Act. 1976. Public Law 94-580, as amended, 90 Stat. 2795, 42 USC 6901 et seq.

Spane, F. A. Jr., P. D. Thorne, and D. R. Newcomer. 2001a. Results of Detailed Hydrologic Characterization Tests - Fiscal Year 1999. PNNL-13378, Pacific Northwest National Laboratory, Richland, Washington.

Spane, F. A. Jr., P. D. Thorne, and D. R. Newcomer. 2001b. Results of Detailed Hydrologic Characterization Tests - Fiscal Year 2000. PNNL-13514, Pacific Northwest National Laboratory, Richland, Washington.

Swanson, L. C. 1994. 1994 Characterization Report for the Proposed State-Approved Land Disposal Site. WHC-SD-C018H-RPT-00, Westinghouse Hanford Company, Richland, Washington.

WAC 173-303-400. Interim Status Facility Standards. Washington Administrative Code, Olympia, Washington.

Waldrop, W. R. and H. S. Pearson. 2000. Results of Field Tests with the Electromagnetic Borehole Flowmeter at the Pacific Northwest National Laboratory, Richland, WA. QEC-T-132, Quantum Engineering Corporation, London, Tennessee.

Williams, B. A, B. N. Bjornstad, R. Schalla, and W. D. Webber. 2002. Revised Hydrogeology for the Superbasalt Aquifer System, 200-West Area and Vicinity, Hanford, Washington. PNNL-13858, Pacific Northwest National Laboratory, Richland, Washington.

Wilson, C. R., C. M. Einberger, R. L. Jackson, and R. B. Mercer. 1992. "Design of Ground-Water Monitoring Networks Using the Monitoring Efficiency Model (MEMO).” Ground Water 30(6):965-970. 


\section{Distribution}

No. of

\section{Copies}

OFFSITE

Confederated Tribes and Bands of the Yakama Indian Nation

Environmental Restoration Waste Management Program

P.O. Box 151

Toppenish, WA 98948

Confederated Tribes of the Umatilla Indian Reservation

P.O. Box 638

Pendleton, OR 97801

Nez Perce Tribe

Nez Perce Tribal Department of

Environmental Restoration and Waste Management

P.O. Box 365

Lapwai, ID 83540

D. A. Dunning

Office of Energy

Nuclear Safety Division

625 Marion Street NE, Suite 1

Salem, OR 97301-3742

\section{ONSITE}

\section{DOE Richland Operations Office}

M. J. Furman

A5-13

J. G. Morse

A5-13

K. M. Thompson

A5-13

Public Reading Room (2)
No. of

Copies

ONSITE

DOE Office of River Protection

R. M. Yasek H6-60

3 CH2M HILL Hanford Group
A. J. Knepp
$\mathrm{H} 0-22$
F. M. Mann
$\mathrm{H} 0-22$
D. A. Myers
$\mathrm{H} 0-22$

4 Washington State Department of Ecology
M. J. Brown
B5-18
J. Caggiano
B5-18
J. A. Hedges
B5-18
A. D. Huckaby
B5-18

14 Pacific Northwest National Laboratory

C. J. Chou

K6-81

J. S. Fruchter

K6-96

D. G. Horton (4)

K6-81

V. G. Johnson

K6-96

S. P. Luttrell

K6-96

L. F. Morasch

K6-86

S. M. Narbutovskih

K6-96

R. M. Smith

K6-96

D. Vela

K6-96

Hanford Technical Library (2) 